\title{
Disease-induced natural selection in a diploid host
}

Andreasen, Viggo; Christiansen, Freddy B.

Publication date:

1991

Document Version

Publisher's PDF, also known as Version of record

Citation for published version (APA):

Andreasen, V., \& Christiansen, F. B. (1991). Disease-induced natural selection in a diploid host. Roskilde Universitet. Tekster fra IMFUFA No. 213 http://milne.ruc.dk/ImfufaTekster/

\section{General rights}

Copyright and moral rights for the publications made accessible in the public portal are retained by the authors and/or other copyright owners and it is a condition of accessing publications that users recognise and abide by the legal requirements associated with these rights.

- Users may download and print one copy of any publication from the public portal for the purpose of private study or research. - You may not further distribute the material or use it for any profit-making activity or commercial gain.

- You may freely distribute the URL identifying the publication in the public portal.

\section{Take down policy}

If you believe that this document breaches copyright please contact rucforsk@kb.dk providing details, and we will remove access to the work immediately and investigate your claim. 


\section{TEKST NR $213 \quad 1991$}

Disease-induced natural selection in a diploid host

by

Viggo Andreasen

and

Freddy B. Christiansen

TEKSTER fra 
IMFUFA, Roskilde Universitetscenter, Postboks 260, 4000 Roskilde

Disease-induced natural selection in a diploid host

by: Viggo Andreasen, Department of Mathematics and Physics,

Roskilde University, DK-4000 Roskilde, Denmark, and

Freddy B. Christiansen, Department of Ecology and Genetics.

University of Aarhus, DK-8000 Arhus C, Denmark.

IMFUFAtekst $n r .213 / 91$

35 pages

ISSN $0106-6242$

\begin{abstract}
:
Using for each genotype an SIR-type model of disease transmission dynamics, we describe natural selection in a continuously breeding diploid host whose disease susceptibility and resistance are carried at one locus with two alleles. The system is transformed into variables that for each disease class describe the number of individuals, the gene frequency, and the deviation from Hardy-Weinberg proportions as measured by Wright's fixation index. An assumption of small variation in disease response among genotypes (slow selection) separates the system to first order into three blocks. One block describes the population wide disease dynamics, one considers the fixation index in each class, and the third block provides the change in gene frequencies. The first two blocks settle to equilibrium at a rate determined by the population turn-over time while the last block after a while is dominated by a slowly changing variable, the average gene frequency. The dynamics of the gene frequency take the usual form for a continuous time slow selection model, and this provides explicit, epidemiologically justified expressions for the genotypic fitnesses. We apply the method to other disease transmission patterns (SEI and $S I S$ ) and discuss how suitable time averages extend our results to diseases with temporally varying incidence.
\end{abstract}

Submitted to Theoretical Population Biology, November 1991 


\section{INTRODUCTION}

Infectious diseases cause mortality, and variation among individuals in susceptibility and sensitivity therefore is subject to natural selection. This phenomenon was investigated by Jayakar (1970), who incorporated the qualitative aspects of the epidemiology into the differential fitness of the genotypes. Gillespie (1975) extended this and developed models of the contribution to genotypic fitnesses by the disease, in that an epidemic is assumed to run through the population each generation. This approach to a more epidemiological fitness formulation was developed further by Lewis (1981), Anderson and May (1982), Longini (1983), and May and Anderson (1983). The mortality of the different genotypes is assumed to be a function of the intensity of the epidemic, and epidemiological equations are used to determine the proportion of hosts that are infected. The host is assumed to have discrete generations with a generation time that is considerably longer than the period of infection. Others have relaxed these assumptions and treated both genetics and disease as continuous processes allowing for the study of endemic diseases (Kemper, 1982).

These studies all assumed that factors other than the disease ultimately regulate the population size, and the link between the evolutionary and the epidemiological parameters is not transparent. Following Beck et al. (1984), we will take another approach and consicler explicit equations for the dynamics of each genotype in the presence of the disease. This allows description of disease-induced density dependent selection in an epidemiologically justified way. Some simplification of the model is needed to further analysis, and we consider only genetic variation at loci with a small effect on susceptibility and sensitivity in the host. That is, we consider the case of slow selection at one locus. Also we assume two alleles and reproduction by random mating, but the approach and the results are rearlily extended to multiple alleles.

A disease model with three epidemic classes and three genotypes in the host is described by $3 \times 3=9$ coupled differential equations. If the genotypes are equal with respect to the disease, the neutral case, then a manifold of equilibria exists characterized by, the epidemiological equilibrium and the Hardy-Weinberg manifold of equilibria characteristic of no selection at one locus. For small fitness differences among the genotypes, the population is expected to move slowly along this manifold. This is the foundation of the slow selection approximation of genetic evolution.

In their analysis of the case of slow selection Beck et al. (1984) applied a rather complicated singular perturbation method involving a variable projection directly onto the slow manifold. The main result of this paper is a major simplification of this method, in that we apply a transformation of the model equations that for the neutral case decouple the dynamics in three blocks, one describing the disease dynamics, one the evolution of the gene frequency, and one block describing the deviation from Hardy-Weinberg proportions. 
After the decoupling Beck's projection method is still needed, but the situation is now considerably less complex, because the singular perturbation needs to be performed only within one block of equations.

In the first section we describe the transformation for a population without disease and show how the selection process essentially is limited to a slow change in gene frequency. Continuous models with explicit description of the dynamics of each genotype has previously been studied (e.g. Nagylaki and Crow, 1974; Hoppensteadt, 1975; Nagylaki, 1977; Freedman and Waltman, 1978; Hunt 1980, 1982) and we compare our results to these. We then turn to the other aspect of the problem, a population with no genetic structure exposed to a contagious disease that is sometimes deathly. Epidemic models with varying population size has recently been studied by several authors, and we summarize only the information that is relevant for our model (Anderson and May, 1979; Getz and Pickering, 1983; Andreasen, 1989; Busenberg and van den Driessche, 1990; Pugliese, 1990a.,b; Busenberg and Hadeler, 1990).

After these preliminaries we can state in section 4 our model that combines the epidemiology with the genetic structure of the host and demonstrate how our transformation simplifies the system. The change in gene frequency can be extracted from the modcl in a slightly complicated way outlined in section 5 . The equation for the change in gene frequency induce an expression for the approximate fitnesses for the genotypes in terms of their effect on the disease parameters of the model. This expression is discussed in scction 6 , and in section 7 we show how our method can be applied to other epidemic situations, and we suggest extensions of the results to diseases that exhibit sustained oscillations. Finally in section 8 the applicability of the approximations is illustrated by numerical examples.

\section{Continuous Genetics with Weak Selection}

Our genetic model describes one autosomal locus with two alleles $A$ and $a$ in a diploid continuously breeding host population. For the sake of simplicity, we assume that the two sexes behave identically with respect to the processes involved. The genetic structure of the population is determined by the density (or number) of each of the three genotypes $A A, A a$, and $a a$, and the densities are denoted $x_{1}, x_{2}$ and $x_{3}$ respectively. Assuming random mating we find that the change in the genotypic densities is given by

$$
\begin{aligned}
& \frac{d x_{1}}{d t}=p^{2} N \bar{B}_{1}\left(x_{1}, x_{2}, x_{3}\right)-M_{1}\left(x_{1}, x_{2}, x_{3}\right) x_{1} \\
& \frac{d x_{2}}{d t}=2 p q N \bar{B}_{2}\left(x_{1}, x_{2}, x_{3}\right)-M_{2}\left(x_{1}, x_{2}, x_{3}\right) x_{2} \\
& \frac{d x_{3}}{d t}=q^{2} N \bar{B}_{3}\left(x_{1}, x_{2}, x_{3}\right)-M_{3}\left(x_{1}, x_{2}, x_{3}\right) x_{3}
\end{aligned}
$$


where $N=x_{1}+x_{2}+x_{3}$ is the total population size while $p=\left(2 x_{1}+x_{2}\right) /(2 N)$ and $q=\left(2 x_{3}+x_{2}\right) /(2 N)$ are the frequencies of alleles of type $A$ and $a$ among the alleles in the population. The average rate of birth of the three genotypes are given by

$$
\begin{aligned}
& \bar{B}_{1}=\frac{1}{p^{2}}\left(B_{11} f_{1}^{2}+\frac{1}{2}\left(B_{12}+B_{21}\right) f_{1} f_{2}+\frac{1}{4} B_{22} f_{2}^{2}\right) \\
& \bar{B}_{2}=\frac{1}{2 p q}\left(\frac{1}{2}\left(B_{12}+B_{21}\right) f_{1} f_{2}+\frac{1}{2}\left(B_{32}+B_{23}\right) f_{2} f_{3}+\frac{1}{2} B_{22} f_{2}^{2}+\left(B_{13}+B_{31}\right) f_{1} f_{3}\right) \\
& \bar{B}_{3}=\frac{1}{q^{2}}\left(B_{33} f_{3}^{2}+\frac{1}{2}\left(B_{32}+B_{23}\right) f_{2} f_{3}+\frac{1}{4} B_{22} f_{2}^{2}\right)
\end{aligned}
$$

where $f_{i}=x_{i} / N, i=1,2,3$, are the frequencies of the three genotypes. We assume that the genotype specific death rates $M_{i}$ and the pair specific birth rates $B_{i j}$ are density dependent and frequency dependent, i. e. that $B_{i j}$ and $M_{i}$ may depend both on the total density $N$ and on the frequencies of the three genotypes. In most of our arguments, however, we will assume an additive specification of the effects of the two sexes on the birth rate. This is avoiding the possibility of complicated dynamics due to fertility selection, and it is equivalent to assuming that only one sex, usually the female, influence the birth rate or that both sexes have equal influence on the birth rate, i. e. we will assume $B_{i j}=B_{i}+B_{j}$ (Nagylaki and Crow, 1974; Feldman et al., 1983).

The model (1) disregards the age structure of the population. Newborn individuals, e.g., reach instant sexual maturity and are counted among reproducing individuals. This is not a particularly reasonable assumption, but it provides a good approximation of the evolutionary process in case of weak selection where the genotype-specific birth and death rates are almost identical. The demographic process then is expected to take place on a time scale faster than the time scale of changes in the gene frequency $p$. The population dynamics is dominated by the characteristics of the average individual, and fast convergence to equilibrium is expected. Therefore, details of the demographic process is less critical as long as the dynamic characteristics of this equilibrium may be described by the simplified model expressed in (1).

We assume that the effects of the alleles are weak in the sense that the genotypespecific birth and death rates are almost identical. The birth and death rates of the genotypes therefore may be written as small deviations from population birth and death rates, in that

$$
\begin{aligned}
B_{i j} & =b(N)+\varepsilon b_{i j}\left(x_{1}, x_{2}, x_{3}\right) \\
M_{i} & =\mu(N)+\varepsilon \mu_{i}\left(x_{1}, x_{2}, x_{3}\right)
\end{aligned}
$$

with $\varepsilon \ll 1$. The birth and death rates are density dependent, but the frequency depenclence is limited to the genotypic deviations, and it is therefore weak. The model is biologically meaningful if we assume that $\mu(\infty)>b(0)>\mu(0)$ and that $\mu(N)$ is an increasing and $b(N)$ is a decreasing function of the population size. With the form (3) of 
the birth and death rates, the model (1) becomes

$$
\begin{aligned}
\frac{d x_{1}}{d t} & =p^{2} N b(N)-\mu(N) x_{1}+\varepsilon \tilde{\psi}_{1}\left(x_{1}, x_{2}, x_{3}\right) \\
\frac{d x_{2}}{d t} & =2 p q N b(N)-\mu(N) x_{2}+\varepsilon \tilde{\psi}_{2}\left(x_{1}, x_{2}, x_{3}\right) \\
\frac{d x_{3}}{d t} & =q^{2} N b(N)-\mu(N) x_{3}+\varepsilon \tilde{\psi}_{3}\left(x_{1}, x_{2}, x_{3}\right)
\end{aligned}
$$

where

$$
\begin{aligned}
& \tilde{\psi}_{1}\left(x_{1}, x_{2}, x_{3}\right)=p^{2} N \bar{b}_{1}\left(x_{1}, x_{2}, x_{3}\right)-\mu_{1}\left(x_{1}, x_{2}, x_{3}\right) x_{1} \\
& \tilde{\psi}_{2}\left(x_{1}, x_{2}, x_{3}\right)=2 p q N \bar{b}_{2}\left(x_{1}, x_{2}, x_{3}\right)-\mu_{2}\left(x_{1}, x_{2}, x_{3}\right) x_{2} \\
& \tilde{\psi}_{3}\left(x_{1}, x_{2}, x_{3}\right)=q^{2} N \bar{b}_{3}\left(x_{1}, x_{2}, x_{3}\right)-\mu_{3}\left(x_{1}, x_{2}, x_{3}\right) x_{3}
\end{aligned}
$$

are describing the selection in the population. The averages, $\bar{b}_{i}$, are given by equations like (2).

The two time scales of the model, the demographic and the evolutionary, will become apparent by a change in variables (Christiansen and Fenchel, 1977). We describe the states of the population by the total size $N=x_{1}+x_{2}+x_{3}$, by the frequency $p$ of alleles $A$, and by Wright's fixation index (Wright, 1969; Nei, 1977),

$$
F=\frac{4 x_{1} x_{3}-x_{2}^{2}}{\left(2 x_{1}+x_{2}\right)\left(2 x_{3}+x_{2}\right)}
$$

for $\left(2 x_{1}+x_{2}\right)\left(2 x_{3}+x_{2}\right) \neq 0$ and $F=0$ when $2 x_{1}+x_{2}=0$ or $2 x_{3}+x_{2}=0$. The quantity $F$ is a density and frequency independent standard measure of how far the population is from the Hardy-Weinberg proportions. When $F=0$, the genotypic frequencies are in HardyWeinberg proportions, i.e., $f_{1}=p^{2}, f_{2}=2 p q$ and $f_{3}=q^{2}$, the frequencies characteristic of the population of newborns. A positive $F$ indicates a higher number of homozygotes than expected with random mating and a negative $F$ shows an excess of heterozygotes. Simple algebra shows that the densities of the genotypes can be recovered from $(N, p, F)$ by the formulas

$$
\begin{aligned}
& x_{1}=\left(p^{2}+p q F\right) N \\
& x_{2}=2 p q(1-F) N \\
& x_{3}=\left(q^{2}+p q F\right) N
\end{aligned}
$$

where $q=1-p$ is the frequency of $a$.

In principle the rate of change of $N, p$, and $F$ can be computed in a strait forward manner using the chain rule. However, the computations get quite involved and it is practical to utilize the transformation properties derived in Appendix A. Using these we 
find

$$
\begin{aligned}
\frac{d N}{d t} & =(b(N)-\mu(N)) N+\varepsilon \psi_{N} \\
\frac{d p}{d t} & =\varepsilon \psi_{p} \\
\frac{d F}{d t} & =-b(N) F+\varepsilon \psi_{F}
\end{aligned}
$$

where the weak selection terms $\psi$ are to be discussed later.

The transformed model (7)-(9) immediately shows that the population dynamics (7) is essentially (to the first order) independent of the genetic structure and takes place on a time scale that is fast compared to the change in gene frequency $p$. Furthermore the deviation from Hardy-Weinberg proportions decreases at a rate that is comparable to the population birth rate $b(N)$ (Nagylaki and Crow, 1974; Christiansen and Fenchel, 1977) which is a measure of the population turn-over time. Our assumptions on $b$ and $\mu$ secure that the population equation

$$
\frac{d N}{d t}=(b(N)-\mu(N)) N
$$

has a stable equilibrium $N^{*}$, and that Hardy-Weinberg proportions, $F=0$, are stable to the first order. The weak selection will not significantly change the equilibrium values of $N$ and $F$, and the dynamics of $p$ can be computed by evaluating $\psi_{p}$ at $(N, p, F)=\left(N^{*}, p, 0\right)$.

Using the transformation (6) we can now compute $\psi_{p}(N, p, F)$ from our knowledge of $\tilde{\psi}_{p}\left(x_{1}, x_{2}, x_{3}\right)$ (Appendix B):

$$
\begin{aligned}
\psi_{p}\left(N^{*}, p, 0\right) & =\tilde{\psi}_{p}\left(p^{2} N^{*}, 2 p q N^{*}, q^{2} N^{*}\right) \\
& =p q\left(\left(\tilde{r}_{1}-\tilde{r}_{2}\right) p-\left(\tilde{r}_{3}-\tilde{r}_{2}\right) q\right)
\end{aligned}
$$

where $\tilde{r}_{i}=\bar{b}_{i}\left(p^{2} N^{*}, 2 p q N^{*}, q^{2} N^{*}\right)-\mu_{i}\left(p^{2} N^{*}, 2 p q N^{*}, q^{2} N^{*}\right)$. Thus the dynamics of $p$ are to the first order given by

$$
\frac{d p}{d t}=\varepsilon p(1-p)\left(\left(\tilde{r}_{1}+\tilde{r}_{3}-2 \tilde{r}_{2}\right) p-\left(\tilde{r}_{3}-\tilde{r}_{2}\right)\right)
$$

This equation simplifies considerably if we assume that the two sexes in a mating contribute additively to the birth rate. This is equivalent to assuming $b_{i j}=b_{i}+b_{j}$ for all $i$ and $j=1,2,3$, and we get

$$
\frac{d p}{d t}=\varepsilon p(1-p)\left(\left(r_{1}+r_{3}-2 r_{2}\right) p-\left(r_{3}-r_{2}\right)\right)
$$

where $r_{i}=b_{i}\left(p^{2} N^{*}, 2 p q N^{*}, q^{2} N^{*}\right)-\mu_{i}\left(p^{2} N^{*}, 2 p q N^{*}, q^{2} N^{*}\right)$ is the net reproductive rate of genotype $i$. 
Equation (10) is the usual equation for slow selection in a random mating population where the change in gene frequency of allele $A$ is proportional to the excess Malthusian parameter for individuals carrying allele $A$ (Norton, 1928; Fisher, 1930; Crow and Kimura, 1970; Nagylaki and Crow, 1974; Nagylaki, 1977):

$$
\frac{d p}{d t}=\varepsilon p\left(p r_{1}+q r_{2}-\bar{r}\right)
$$

where $\bar{r}=p^{2} r_{1}+2 p q r_{2}+q^{2} r_{3}$ is the mean Malthusian parameter and $p r_{1}+q r_{2}$ is the average Malthusian parameter for allele $A$. The equation may also be expressed in terms of the difference between the average Malthusian parameter of allele $A$ and the average Malthusian parameter of allele $a$ in the population:

$$
\frac{d p}{d t}=\varepsilon p q\left(\left(p r_{1}+q r_{2}\right)-\left(p r_{2}+q r_{3}\right)\right)
$$

The three ways of writing equation (10) are entirely equivalent, and for this kind of equation we will use the short form

$$
\frac{d p}{d t}=\varepsilon p q\left\langle r_{i} \mid p\right\rangle
$$

where $\left\langle r_{i} \mid p\right\rangle=p r_{1}+(q-p) r_{2}-q r_{3}$ is the difference between the mean $r$ of allele $A$ and the mean $r$ of allele $a$ in a population with gene frequencies $p$ and $q=1-p$.

Equation (10) gives the well known condition for the existence of a polymorphic equilibrium, namely that the heterozygote must have a higher net reproductive rate than either of the homozygotes or a lower net reproductive rate than either homozygote. Equation (10) has three equilibria, two fixation equilibria at $p=0,1$, and an equilibrium at $p=p^{*}$ with

$$
p^{*}=\frac{r_{3}-r_{2}}{r_{1}+r_{3}-2 r_{2}}
$$

The equilibrium $p^{*}$ is stable and biologically meaningful (i.e. $0<p^{*}<1$ ) if and only if $r_{1}<r_{2}$ and $r_{3}<r_{2}$. If $r_{2}<r_{1}, r_{3}$, then $p^{*}$ determines an unstable equilibrium dividing the set of gene frequencies that lead to fixation of either of one or the other allele.

The result (10) is similar to the result of Nagylaki and Crow (1974) and Nagylaki (1977) who used a linear measure (corresponding to $F p q$ ) of the deviation from HardyWeinberg proportions. Hoppensteadt (1975) analyzed a model like (4) by transforming to genotype frequencies and applying a version of matched asymptotic expansions with multiple time scales. Using similar methods Aronson and Weinberger (1975) and Hunt (1980, 1982) analyzed spatial diffusion of genes and slow selection, slow population growth. The condition for polymorphism is well known (Norton, 1928; Fisher, 1930).

The analysis in this section shows that the transformation to $(N, p, F)$ explicitly express how the dynamics splits in two time scales, and this method facilitates the combination of epidemiology and host genetics. The method has been developed under the 
assumption of two alleles, but it generalizes immediately to multiple alleles as the properties of Wright's fixation index is shared by similar indices for multiple alleles (Nei, 1977).

\section{Disease Dynamics}

Consider a disease with no latent period, and assume that individuals once recovered, acquire permanent immunity. Transmission is purely horizontal and no vertical transmission takes place. Infection may alter mortality, but does not reduce fertility. In section 7 we will return to a discussion of some of these assumptions and consider modifications of the disease etiology. The population is divided into three epidemic classes, with $S$ susceptibles, $I$ infectious, and $R$ recovered individuals, and the total population size is $N=S+I+R$. The population is well mixed so the rate at which susceptibles get infected, the force of infection $\Lambda$, is proportional to $I$, in that $\Lambda=\beta I$. The rate of recovery of infected individuals is $\nu$. The birth rate in the population is $b$, the death rate of individuals without the disease is $\mu$, and the infected individuals has an excess mortality given by $\alpha$. This produces the well known host regulation model (Anderson and May, 1979)

$$
\begin{aligned}
& \frac{d S}{d t}=b N-\mu S-\beta S I \\
& \frac{d I}{d t}=\beta S I-(\nu+\mu+\alpha) I \\
& \frac{d R}{d t}=\nu I-\mu R
\end{aligned}
$$

The population birth-rate $b$ depends in general on the density and composition of the population. However, in describing the dependence on the disease state we will restrict attention to an additive specification of the birth rate of a pair of individuals similar to the assumptions made in the genetic model, and we will assume that mating is random with respect to disease class (i. e. $b_{S S}=b_{S}, b_{S I}=\left(b_{S}+b_{I}\right) / 2 \ldots$ ). Therefore, the population birth rate can be specified as

$$
b(S, I, R)=\frac{1}{N}\left(b_{S}(N) \frac{S}{N}+b_{I}(N) \frac{I}{N}+b_{R}(N) \frac{R}{N}\right)
$$

The excess mortality of infected individuals make the host population-size dependent on the level of the disease, and the model allows for density dependence in both mortality $\mu$ and disease transmission $\beta$. We will assume that the disease cannot increase fertility $b_{S}(N) \geq b_{I}(N), b_{R}(N)$ and that the birth rates $b_{Q}(N)$ are decreasing functions of $N$ while the mortality $\mu(N)$ is an increasing function with $\mu_{\infty}>b_{S}(0)>\mu(0)$. The contact rate $\beta(N) N$ is assumed to be non-decreasing.

Using the methods of Pugliese (1990a), Andreasen (1989), and Busenberg and van den Driessche (1990) one can show that the dynamical behavior of (12) is characterized 
by the reproduction number

$$
\mathcal{R}(N)=\frac{\beta(N) N}{\mu(N)+\nu+\alpha}
$$

The clisease free equilibrium $S=\hat{N}$ determined by $b_{S}(\hat{N})=\mu(\hat{N})$ is asymptotically stable if $\mathcal{R}(\hat{N})<1$. When $\mathcal{R}(\hat{N})>1$ the disease will persist and there exists a stable endemic equilibrium with some population density $N^{*-}<\hat{N}$. The decrease in population size due to the pressure of the disease is an expression of the ability of the disease to slow the growth of the host population.

Although model (12) is formally similar to the well known SIR-models with fixed population size (Hethcote, 1974; Dietz, 1975) it is founded on very different the biological assumptions. The host regulation model (12) describes the interaction between population size and disease transmission, and the density dependence of the disease transmission is decisive for the resulting dynamics of the model (Getz and Pickering, 1983; Andreasen, 1989). In adclition, the mathematical properties of model (12) deviate from those of the SIRmodels. For instance, the introduction of a latent period in the host regulation model may lead to sustained oscillations (Anderson et al., 1981; Swart, 1989; Pugliese, 1990b), a behavior unknown in models with fixed population size. The assumption of an additive. structure in the birth rate seems to be necessary to maintain the simple dynamics. If the fertility contribution of a disease-free individual is lowered when mating a diseased individual then quite complicated dynamics may result (Diekmann and Kretzschmar 1991).

\section{Weak Disease Induced Selection}

The combination of the models from the two previous sections provides an epidemiologically justified model that describes the population dynamics at the genotype level. We assume that the population mates at random, not only with respect to genotype, but also with respect to disease class. To maintain the simplifications obtained by this assumption we also assume that additivity of the genotypic influence on the birth rate and for simplicity we formulate the equations assuming equal birth rate in the disease classes. Further, we assume that infectivity is independent of genotype. Since the infectivity enters only through the magnitude of the force of infection $\Lambda$, genetically determined variation in infectivity will not lead to a differential change in survival as long as all genotypes mix homogeneously during disease transmission.

The subscripted parameters will indicate the small genotypic variation in parameters as in equation (3), and parameters without subscript describe the main population dynamics as in equation (12). The variables are subscripted according to genotypic class, and a variable without a subscript denotes summation over all genotypes. The dynamics of the 
combined model is then given by

$$
\begin{aligned}
\frac{d S_{1}}{d t} & =p^{2} N\left(b+\varepsilon \bar{b}_{1}\right)-\left(\mu+\varepsilon \mu_{1}\right) S_{1}-\left(\beta+\varepsilon \beta_{1}\right) S_{1} I \\
\frac{d S_{2}}{d t} & =2 p q N\left(b+\varepsilon \bar{b}_{2}\right)-\left(\mu+\varepsilon \mu_{2}\right) S_{2}-\left(\beta+\varepsilon \beta_{2}\right) S_{2} I \\
\frac{d S_{3}}{d t} & =q^{2} N\left(b+\varepsilon \bar{b}_{3}\right)-\left(\mu+\varepsilon \mu_{3}\right) S_{3}-\left(\beta+\varepsilon \beta_{3}\right) S_{3} I \\
\frac{d I_{1}}{d t} & =\left(\beta+\varepsilon \beta_{1}\right) S_{1} I-\left(\mu+\varepsilon \mu_{1}\right) I_{1}-\left(\nu+\varepsilon \nu_{1}\right) I_{1}-\left(\alpha+\varepsilon \alpha_{1}\right) I_{1} \\
\frac{d I_{2}}{d t} & =\left(\beta+\varepsilon \beta_{2}\right) S_{2} I-\left(\mu+\varepsilon \mu_{2}\right) I_{2}-\left(\nu+\varepsilon \nu_{2}\right) I_{2}-\left(\alpha+\varepsilon \alpha_{2}\right) I_{2} \\
\frac{d I_{3}}{d t} & =\left(\beta+\varepsilon \beta_{3}\right) S_{3} I-\left(\mu+\varepsilon \mu_{3}\right) I_{3}-\left(\nu+\varepsilon \nu_{3}\right) I_{3}-\left(\alpha+\varepsilon \alpha_{3}\right) I_{3} \\
\frac{d R_{1}}{d t} & =\left(\nu+\varepsilon \nu_{1}\right) I_{1}-\left(\mu+\varepsilon \mu_{1}\right) R_{1} \\
\frac{d R_{2}}{d t} & =\left(\nu+\varepsilon \nu_{2}\right) I_{2}-\left(\mu+\varepsilon \mu_{2}\right) R_{2} \\
\frac{d R_{3}}{d t} & =\left(\nu+\varepsilon \nu_{3}\right) I_{3}-\left(\mu+\varepsilon \mu_{3}\right) R_{3}
\end{aligned}
$$

where the average rate of birth of the three genotypes is calculated assuming equal birth rates for all disease classes, i. e. $\bar{b}_{i}$ is given by equations like (2) with $f_{i}=\left(S_{i}+I_{i}+R_{i}\right) / N$.

The coordinate transformation into $(N, p, F)$-space is applied for each disease class, so we t,ransform the equations into $\left(Q, p_{Q}, F_{Q}\right)$-space, $Q=S, I, R$. For notational convenience let $\bar{p}=\left(p_{S} S+p_{I} I+p_{R} R\right) / N$ denote the gene frequency in the total population. The transformation properties from Appendix A allows equation (14) to be substituted by the equations

$$
\begin{aligned}
\frac{d S}{d t} & =b N-\mu S-\beta S I+\varepsilon \psi_{S} \\
\frac{d I}{d t} & =\beta S I-(\nu+\mu+\alpha) I+\varepsilon \psi_{I} \\
\frac{d R}{d t} & =\nu I-\mu R+\varepsilon \psi_{R} \\
\frac{d p_{S}}{d t} & =b \frac{I}{S}\left(p_{I}-p_{S}\right)+b \frac{R}{S}\left(p_{R}-p_{S}\right)+\varepsilon \psi_{p s} \\
\frac{d p_{I}}{d t} & =\beta S\left(p_{S}-p_{I}\right)+\varepsilon \psi_{p i} \\
\frac{d p_{R}}{d t} & =\nu \frac{I}{R}\left(p_{I}-p_{R}\right)+\varepsilon \psi_{p r}
\end{aligned}
$$




$$
\begin{aligned}
& \frac{d F_{S}}{d t}=b \frac{N}{S}\left(\frac{\left(\bar{p}-p_{S}\right)^{2}}{p_{S} q_{S}}\left(1-F_{S}\right)-\frac{\bar{p} \bar{q}}{p_{S} q_{S}} F_{S}\right)+\varepsilon \psi_{F S} \\
& \frac{d F_{I}}{d t}=\beta S\left(\frac{\left(p_{S}-p_{I}\right)^{2}}{p_{I} q_{I}}\left(1-F_{I}\right)-\frac{p_{S} q_{S}}{p_{I} q_{I}}\left(F_{I}-F_{S}\right)\right)+\varepsilon \psi_{F I} \\
& \frac{d F_{R}}{d t}=\frac{\nu I}{R}\left(\frac{\left(p_{I}-p_{R}\right)^{2}}{p_{R} q_{R}}\left(1-F_{R}\right)-\frac{p_{I} q_{I}}{p_{R} q_{R}}\left(F_{R}-F_{I}\right)\right)+\varepsilon \psi_{F R}
\end{aligned}
$$

where the second order terms $\psi$ are discussed later.

To the first order, the dynamics of (15)-(17) splits up in a) an SIR-dynamics which is independent of the genetic structure b) a gene frequency dynamics which depends only on $S I R$ and on the gene frequencies and c) the dynamics of the deviation from HardyWeinberg proportions.

The dynamics of the SIR-model was discussed in the previous section, and we will assume that the parameters are chosen so the system (15) settles at a locally stable endemic equilibrium $\left(S^{*}, I^{*}, R^{*}\right)$ for $\varepsilon=0$.

The second part of the transformed equations, (16), contains a one-dimensional singularity $p_{S}=p_{I}=p_{R}=p$ for $\varepsilon=0$. This manifold is stable, i.e., $\left(p_{S}, p_{I}, p_{R}\right) \rightarrow(p, p, p)$ for $t \rightarrow \infty$. To see this, consider the variables $\xi_{1}=p_{S}-p_{I}$ and $\xi_{2}=p_{S}-p_{R}$, and observe that

$$
\begin{aligned}
& \frac{d \xi_{1}}{d t}=-\left(b \frac{I}{S}+\beta S\right) \xi_{1}-b \frac{R}{S} \xi_{2} \\
& \frac{d \xi_{2}}{d t}=\left(-b \frac{I}{S}+\nu \frac{I}{R}\right) \xi_{1}-\left(\nu \frac{I}{R}+b \frac{R}{S}\right) \xi_{2} .
\end{aligned}
$$

This system has a unique fixed point at $\left(\xi_{1}, \xi_{2}\right)=(0,0)$. Since equations (18) are of the form $d \xi / d t=(A+B(t)) \xi$ where the eigenvalues of $A$ have negative real part and $B(t) \rightarrow 0$ for $t \rightarrow \infty$, we have $\xi_{1}(t), \xi_{2}(t) \rightarrow 0$ for $t \rightarrow \infty$ (Coddington and Levinson, 1955, p316).

The right hand sides of the equations (17) for the deviation from Hardy-Weinberg proportions are discontinuous at $p_{Q}=0$ and $p_{Q}=1$ corresponding to fixation of one allele in a disease class, $Q=S, I, R$. However, if we define $d F_{Q} / d t$ as zero when $\bar{p}=0$ or 1 , then the equations extends naturally to describe the dynamics of the $F_{S}, F_{I}$ and $F_{R}$ in the closed interval $[0,1]$. To see this we need to analyze the behavior of $F_{Q}$ when initially one of the corresponding gene frequencies is zero, i. e., for $p_{Q}(0)=0$ or 1 .

Assume that the allele $A$ initially is present only among diseased or recovered indivicluals, i. e. $p_{S}(0)=0$. Then the class of susceptibles consists of $a a$ individuals and the genotypic composition is gradually changed by the birth of individuals with allele $A$ in the frequency $\vec{p} \neq 0$. For $\varepsilon=0$ we get from equation (14) that

$$
p_{S}(t) \approx \frac{\bar{p} b N t}{S} \text { for } t \rightarrow 0
$$


The genotypic frequencies among newborns are in Hardy-Weinberg proportions with gene frequency $\bar{p}$ and the initial population is in Hardy-Weinberg proportions with gene frequency 0 . Then from equation (6) we get

$$
F_{S}(t)=1-\frac{2 \bar{p} \bar{q} b N t}{2(\bar{p} b N t)}+O(t)
$$

so $F_{S}(t) \rightarrow \bar{p}$ for $t \rightarrow 0$, and the mixture of the populations produce a deviation, from the Hardy-Weinberg proportions due to the Wahlund effect (Christiansen, 1988). Thus, equation (17) approximately reads as

$$
\frac{d F_{S}}{d t} \approx-\frac{2 \bar{p} \bar{q} b N}{S}
$$

as long as $p_{S}$ is small. For $p_{I}(0)=0$ we get in a similar way that

$$
p_{I}(t) \approx p_{S} \beta S t \quad \text { and } \quad F_{I}(t) \approx 1-\frac{2 p_{S} q_{S}\left(1-F_{S}\right) \beta S I t}{2\left(p_{S} \beta S I t\right)}
$$

so $F_{I}(t) \rightarrow p_{S}+q_{S} F_{S}$ for $t \rightarrow 0$. Therefore, equation $(17)$ becomes $d F_{I} / d t \approx-2 p_{S} q_{S}(1-$ $\left.F_{S}\right) \beta S$ as long as $p_{I}$ is small. Finally, for $p_{R}(0)=0$ we get that $F_{R}(t) \rightarrow p_{I}+q_{I} F_{I}$ for $t \rightarrow 0$ and equation (17) is $d F_{R} / d t \approx-2 p_{I} q_{I}\left(1-F_{I}\right) \nu I / R$ as long as $p_{R}$ is small. The equations (17) are therefore bounded and well behaved for $\bar{p}$ in the open interval $(0,1)$. Then for any initial composition of the population we have that $\left(F_{S}, F_{I}, F_{R}\right) \rightarrow(0 ; 0,0)$ for $t \rightarrow \infty$ since the quadratic terms in $\left(\bar{p}-p_{Q}\right)$ go to zero.

We conclude that equations (15)-(17) for $\varepsilon=0$ contains a 1-dimensional stable manifold of fixed points

$$
\varpi_{0}(p)^{T}=\left(S, I, R, p_{S}, p_{I}, p_{R}, F_{S}, F_{I}, F_{R}\right)=\left(S^{*}, I^{*}, R^{*}, p, p, p, 0,0,0\right),
$$

where $T$ denotes the transposed. The interaction between the epidemiologically determined host regulation and other population processes is therefore independent of the gene frequency on the fast time scale. Furthermore the population will attain Hardy-Weinberg proportions and identical gene frequencies $p$ in all disease classes on this time scale. The change in gene frequency $p$ occurs on the slow time scale determined by the second order terms which is the subject of the next section.

\section{The Change in Gene Frequency}

The dynamics of the gene frequency $p$ is investigated by applying the singular perturbation method of Beck et al. (1984) to the system of equations (15)-(17). These equations may be written in the form

$$
\frac{d y}{d t}=G(y)+\varepsilon \Psi(y)
$$


where $y, G$, and $\Psi$ are nine-dimensional vectors. The equation $G(y)=0$ has a one parameter family of solutions $y=\varpi_{0}(p)$ given by equation (19), and this solution is stable for $\varepsilon=0$ so $G^{\prime}\left(\varpi_{0}(p)\right)$ has eight eigenvalues with negative real part bounded away from 0 and one zero eigenvalue.

For $\varepsilon \neq 0$ we search for solutions to the equation $d y / d t=G(y)+\varepsilon \Psi(y)$ close to the stable manifold (19). These solutions will have the form

$$
y(t)=y_{0}(t)+\varepsilon y_{1}(t, \varepsilon)=\varpi_{0}(p(t))+\varepsilon y_{1}(t, \varepsilon)
$$

in that $y_{0}$ is on the stable manifold. In equation (20) this expansion produces the form

$$
\varpi_{0}^{\prime}(p) \frac{d p}{d t}+\varepsilon \frac{\partial y_{1}}{\partial t}=G\left(\varpi_{0}(p)\right)+\varepsilon G^{\prime}\left(\varpi_{0}(p)\right) y_{1}+\varepsilon \Psi\left(\varpi_{0}(p)\right)+O\left(\varepsilon^{2}\right) .
$$

We separate the dynamics of $p$ and $y_{1}$ by projecting onto a left-hand zero eigenvector $w(p)$ of $G^{\prime}(\varpi(p))$ and onto its orthogonal complement $w(p)^{\perp}$. The ordinary inner product is denoted by $[\cdot \mid \cdot]$ and the projection onto $w(p)^{\perp}$ by $P$ which is given by $P u=u-[w \mid u] w /|w|^{2}$, where $|w|^{2}=[w \mid w]$. The change parallel to $w(p)$ is given by

$$
\left[w(p) \mid \varpi_{0}^{\prime}(p)\right] \frac{d p}{d t}+\varepsilon\left[w \mid \frac{\partial y_{1}}{\partial t}\right]=\varepsilon\left[w \mid \Psi\left(\varpi_{0}(p)\right)\right]+O\left(\varepsilon^{2}\right)
$$

and the change orthogonal to $w(p)$ is given by

$$
P \varpi_{0}^{\prime}(p) \frac{d p}{d t}+\varepsilon P \frac{\partial y_{1}}{\partial t}=\varepsilon P G^{\prime}\left(\varpi_{0}(p)\right) y_{1}+\varepsilon P \Psi\left(\varpi_{0}(p)\right)+O\left(\varepsilon^{2}\right)
$$

Many expansions like (21) exists, and we choose to consider only an expansion where $\left[w(p) \mid \partial y_{1} / \partial t\right]=0$ because a zero eigenvector of $G^{\prime}(\varpi(p))$ is tangent to the stable manifold $\varpi_{0}$. Thus, in the expansions (21) the variable $y_{1}$ express the direction and relative magnitude of the deviation of $y$ from $\varpi_{0}$. This requirement allows a decoupling of the dynamics of $p$ from the dynamics of $y$. Rearrangement of (22) provides the final expression for $d p / d t$. as

$$
\frac{d p}{d t}=\varepsilon \frac{\left[w \mid \Psi\left(\varpi_{0}\right)\right]}{\left[w \mid \varpi_{0}^{\prime}\right]}
$$

cxcept for terms of the order $\varepsilon^{2}$ or smaller.

To find the normalized zero eigenvector $w /\left[w \mid \varpi_{0}^{\prime}\right]$ observe that $G^{\prime}\left(\varpi_{0}(p)\right)$ is a block diagonal matrix. The upper left block and the lower right block correspond to the $S I R$, and the $F$ dynamics, respectively. These two blocks are both invertible, so the zero cigenvector w) will vanish on these coordinates. For the remainder of this section we therefore may restrict our attention to the three coordinates describing the gene frequency. The conlice 
three by three block of $G^{\prime}\left(\varpi_{0}(p)\right)$ is independent of $p$, and from equations (16) it is given by

$$
G_{p}^{\prime}\left(\varpi_{0}(p)\right)=\left(\begin{array}{ccc}
-b \frac{I+R}{S} & b \frac{I}{S} & b \frac{R}{S} \\
\beta S & -\beta S & 0 \\
0 & \nu \frac{I}{R} & -\nu \frac{I}{R}
\end{array}\right)
$$

where all quantities are evaluated at the endemic equilibrium. The mean residence time in a disease class of an individual that enters the class at the endemic equilibrium are $\delta_{S}=S /(b N)=(\mu+\beta I)^{-1}, \delta_{I}=(\beta S)^{-1}=(\mu+\nu+\alpha)^{-1}$, and $\delta_{R}=R /(\nu I)=\mu^{-1}$ (see equation (12)), so we may write

$$
G_{p}^{\prime}\left(\varpi_{0}(p)\right)=\left(\begin{array}{ccc}
-\delta_{S}^{-1} \frac{I+R}{N} & \delta_{S}^{-1} \frac{I}{N} & \delta_{S}^{-1} \frac{R}{N} \\
\delta_{I}^{-1} & -\delta_{I}^{-1} & 0 \\
0 & \delta_{R}^{-1} & -\delta_{R}^{-1}
\end{array}\right)
$$

The zero eigenvector $w$ of this block is therefore independent of the gene frequency $p$, and we get

$$
w_{p}=\left(w_{1}, w_{2}, w_{3}\right)=\left(\delta_{S}(S+I+R), \delta_{I}(I+R), \delta_{R} R\right)
$$

Since $\varpi_{0}^{\prime}(p)$ is $(1,1,1)$ on the three $p$ dimensions, we have $\left[w \mid \varpi_{0}^{\prime}\right]=w_{1}+w_{2}+w_{3}=\|w\|$, where $\|\cdot\|$ denotes the 1 -norm of the vector, i.e. $\|w\|=\left|w_{1}\right|+\left|w_{2}\right|+\left|w_{3}\right|$. The components of the zero eigenvector $w$ is the total time the individuals in the population spend in the three disease classes. Thus, the components of the normalized zero eigenvector $w /\left[w \mid \varpi_{0}^{\prime}\right]=$ $w /\|w\|$ express the fraction of their life time individuals spend in the three disease classes.

The second order terms of equations (16) can be computed as described in Appendix $B$, and by the assumption of additive contributions of the sexes to the birth rate we get

$$
\begin{aligned}
& \psi_{p s}=p q\left\langle b_{i} N / S-\mu_{i}-\beta_{i} I \mid p\right\rangle \\
& \psi_{p i}=p q\left\langle\beta_{i} S-\left(\mu_{i}+\nu_{i}+\alpha_{i}\right) \mid p\right\rangle \\
& \psi_{p r}=p q\left\langle\nu_{i} I / R-\mu_{i} \mid p\right\rangle
\end{aligned}
$$

where all quantities are evaluated at the endemic equilibrium and as before we use

$$
\left\langle k_{i} \mid p\right\rangle=p k_{1}+(q-p) k_{2}-q k_{3}=\left(p k_{1}+q k_{2}\right)-\left(p k_{2}+q k_{3}\right)
$$

for the difference between the average $k$ 's of allele $A$ and allele $a$. Inserting $\Psi\left(\varpi_{0}\right)$ from equations (26) into equation (23) provide the equation for the slow dynamics along $\varpi_{0}$ as

$$
\begin{gathered}
\frac{d p}{d t}=\varepsilon p q\left(\frac{N}{S} \frac{w_{1}}{\|w\|}\left\langle b_{i} \mid p\right\rangle-\left\langle\mu_{i} \mid p\right\rangle-\left(\frac{w_{1}}{\|w\|} \frac{I}{S}-\frac{w_{2}}{\|w\|}\right)\left\langle\beta_{i} S \mid p\right\rangle\right. \\
\left.-\frac{w_{2}}{\|w\|}\left\langle\alpha_{i} \mid p\right\rangle+\left(\frac{w_{3}}{\|w\|} \frac{I}{R}-\frac{w_{2}}{\|w\|}\right)\left\langle\nu_{i} \mid p\right\rangle\right) .
\end{gathered}
$$


This equation provides a good approximate description of the dynamics of the gene frequency. A result by Hoppensteadt $(1966,1971)$ shows that if $(28)$ has an equilibrium, stable a.t an exponential rate, then there exists a $t_{0}$ such that the solution $p_{\varepsilon}(t)$ to $(28)$ will converge to the solution obtained from the system (14) uniformly in $\varepsilon$ on all closed subintervals of the interval $\left[t_{0} ; \infty\right)$. Otherwise, if equation (28) has a stable equilibrium the solution to (28) will converge uniformly in $\varepsilon$ on intervals $\left[t_{0} ; T / \varepsilon\right)$.

\section{APPROXimate Genotypic Fitnesses}

The form of equation (28) invites an immediate parallel to the classical population genetic equation (11), in that it may be written as

$$
\frac{d p}{d t}=\varepsilon p q\left\langle s_{i} \mid p\right\rangle,
$$

where $\left\langle s_{i} \mid p\right\rangle=\left(p s_{1}+q s_{2}\right)-\left(p s_{2}+q s_{3}\right)$ and

$$
s_{i}=\frac{N}{S} \frac{w_{1}}{\|w\|} b_{i}-\mu_{i}-\left(\frac{w_{1}}{\|w\|} \frac{I}{S}-\frac{w_{2}}{\|w\|}\right) \beta_{i} S-\frac{w_{2}}{\|w\|} \alpha_{i}+\left(\frac{w_{3}}{\|w\|} \frac{I}{R}-\frac{w_{2}}{\|w\|}\right) \nu_{i} .
$$

Thus, we can define Malthusian parameters for the three genotypes by $r+\varepsilon s_{1}, r+\varepsilon s_{2}$ and $r+\varepsilon s_{3}$ of genotype $A A, A a$ and $a a$, and recover equation (28) as a version of equation (11). In this sense, equation (28) provides a definition of fitness induced by variation in reaction to an epidemic disease described by an SIR-model.

In the fitness parameters, $s_{i}$, the genetically determined variation in disease characteristics is weighted by a factor which measure the relative contribution to reproduction of the disease class in which the characteristic is acting. The contribution of the genotypic variation in the parameters is determined by weights $w$ which are closely linked to the fraction of the host life span during which the host is subjected to the action of the parameter, e. g. the importance of a higher recovery rate $\nu$ depends on the expected time spend in $I$ and $R$ while the importance of the morbidity rate $\alpha$ depends only on the time spend in the infectious class.

The fitness contributions of the death rate parameters $\mu_{i}$ and $\alpha_{i}$ are always negative, and the fitness contribution of the birth rate parameters $b_{i}$ is positive. The fitness contributions of variations $\beta_{i}$ in the infection rate coefficient and of variations $\nu_{i}$ in the rccovery parameters may be evaluated assuming equilibrium in the fast disease dynamics. At steady state of the disease we get from equations (12) that $I=R \mu / \nu, \beta S=\mu+\nu+\alpha$ and $(b-\mu) N=\alpha I$. Using these relations we get

$$
w_{1} \frac{I}{S}-w_{2}=\frac{1}{b \beta S}(\beta I S-b(I+R))=\frac{b-\mu}{\beta b}
$$


which is positive when $\alpha>0$ because then $b>\mu$ from our assumptions. Thus, the fitness contributions of variations in $\beta$ are negative. When $\alpha=0$ we get the equilibrium population size determined from the equation $b(\hat{N})=\mu(\hat{N})$, and variation in the infection rate coefficient $\beta$ as expected is neutral to the first order. The fitness contribution of variations $\nu_{i}$ in the recovery parameters are positive when $\alpha>0$, because we have

$$
w_{3} \frac{I}{R}-w_{2}=\frac{\alpha}{\nu \beta} \frac{R}{S}
$$

Again, if $\alpha=0$ variations in the recovery parameter is neutral to the first order. The qualitative influence of genotypic variation in the genotypic parameters $b_{i}, \mu_{i}, \alpha_{i}, \nu_{i}$ and $\beta_{i}$ therefore is fixed in the SIR host regulation model (12), in that $b_{i}$ and $\nu_{i}$ provide a positive contribution to fitness and $\mu_{i}, \alpha_{i}$ and $\beta_{i}$ have a negative contribution to $s_{i}$. The relative importance of the genotypic parameters, however, depends on the quantitative characteristics of the disease.

The different weights of variations in the basic birth and death rates may be a bit surprising. However, for $\alpha=0$ we have $w_{1} /\|w\|=S / N$ so the ordinary Malthusian fitness parameter $b_{i}-\mu_{i}$ is recovered. With the disease present and $\alpha>0$ the mortality rate varies through the life of an individual, so the birth rate $b$ and the death rate $\mu$ are no longer the sole determinants of the population growth rate.

The genotypic fitness definition in equation (29) is in terms of a linear combination of the contribution to fitness of the variation in the epidemiological and demographic parameters as one would expect since we have only retained first order effects. The change in mean fitness also is well characterized as long as the SIR-model that governs the fast dynamics of the model is unchanged, i. e., as long as the coefficients in definition (29) remain fixed. The mean fitness always increases except in a population in genetic equilibrium (Fisher, 1930; Kimura, 1958). The condition for polymorphism is equivalent to the condition that the net growth rate of the heterozygotes exceeds that of both homozygotes, $s_{1}, s_{3}<s_{2}$.

The relations (30) and (31) may be used to simplify equation (29), and by measuring $s_{i}$ in units of the Malthusian parameter $b-\mu$ we get

$\frac{s_{i}}{b-\mu}=\frac{\mu}{b-\mu} \frac{N}{\mu\|w\|} \frac{b_{i}}{b}-\frac{\mu}{b-\mu} \frac{\mu_{i}}{\mu}-\frac{\mu}{b} \frac{S}{\mu\|w\|} \frac{\beta_{i}}{\beta}+\frac{\nu}{\mu+\nu+\alpha} \frac{N}{\mu\|w\|}\left(\frac{\nu_{i}}{\nu}-\left(1+\frac{\mu}{\nu}\right) \frac{\alpha_{i}}{\alpha}\right)$,

where

$$
\mu\|w\|=\frac{\mu}{b} S+\left(1+\frac{\mu(\mu+\nu)}{\nu(\mu+\nu+\alpha)}\right) R
$$

Thus, relative measures of the genotypic variation in the disease parameters seems as natural as the linear measures that we used in the formulation of model (14). 


\subsection{Disease of short duration}

For a disease of short duration, where $\mu / \nu$ is small, we see from (32) that similar relative variations in the values of $\alpha$ and $\nu$ will have comparable effects on the fitness. Also when the disease duration is short and the added mortality is low, $\alpha$ small, we get $\mu / b \approx 1$ and $\mu\|w\| \approx N$ so

$$
\frac{s_{i}}{b-\mu} \approx \frac{\overline{b_{i}-\mu_{i}}}{b-\mu}-\frac{S}{N} \frac{\beta_{i}}{\beta}+\frac{\nu_{i}}{\nu}-\frac{\alpha_{i}}{\alpha}
$$

A childhood disease is characterized by a lārge fraction of recovered and immune indiviclu als in the population. Thus, we expect relative variations in $\alpha$ and $\nu$ to outweigh variations in $\beta$. Since the reproduction number, $\mathcal{R}$ in (13), is typically in the range 4-20 for viral childhood diseases (Anderson, 1982), we expect $S / N$ to be in the range 0.05-0.25, so the contrast in fitness effects may be quite large. However, variations in the three epidemiological parameters have about equal weights in a disease which affects only a low proportion of the individuals in the population. The infection rate coefficient $\beta$ determines the rate of entrance into a period of increased mortality, and small variations in this parameter are not very important if almost all individuals enter this state early in life.

\subsection{Disease effects on the birth rates}

Differences between the three disease classes in birth rates complicates equations (16) and (17). The change in genotypic frequencies between the disease classes may result, in deviations from Hardy-Weinberg proportions among newborns in the $S$-class. This deviation, however, is of order $\varepsilon$, so the convergence of $F$ to zero is maintained when $\varepsilon=0$. Therefore, we only need to examine equations (16), where only the first equation changes and becomes

$$
\begin{aligned}
\frac{d p_{S}}{d t}=b_{I} & \frac{I}{S}\left(p_{I}-p_{S}\right)+b_{R} \frac{R}{S}\left(p_{R}-p_{S}\right)+\frac{1}{2}\left(b_{I}-b_{R}\right) \frac{I R}{S N}\left(p_{R}-p_{I}\right) \\
& +\frac{1}{2}\left(b_{S}-b_{I}\right) \frac{I}{N}\left(p_{I}-p_{S}\right)+\frac{1}{2}\left(b_{S}-b_{R}\right) \frac{R}{N}\left(p_{R}-p_{S}\right)+\varepsilon \psi_{p s}
\end{aligned}
$$

The derivative $G_{p}^{\prime}\left(\varpi_{0}(p)\right)$ now becomes

$$
\left(\begin{array}{ccc}
g_{1} & g_{2} & g_{3} \\
\beta S & -\beta S & 0 \\
0 & \nu \frac{I}{R} & -\nu \frac{I}{R}
\end{array}\right)
$$

where

$$
\begin{aligned}
& g_{1}=-b_{I} \frac{I}{S}-b_{R} \frac{R}{S}-\frac{1}{2}\left(b_{S}-b_{I}\right) \frac{I}{N}-\frac{1}{2}\left(b_{S}-b_{R}\right) \frac{R}{N} \\
& g_{2}=b_{I} \frac{I}{S}+\frac{1}{2}\left(b_{S}-b_{I}\right) \frac{I}{N}-\frac{1}{2}\left(b_{I}-b_{R}\right) \frac{I R}{S N} \\
& g_{3}=b_{R} \frac{R}{S}+\frac{1}{2}\left(b_{S}-b_{R}\right) \frac{R}{N}+\frac{1}{2}\left(b_{I}-b_{R}\right) \frac{I R}{S N}
\end{aligned}
$$


and the fitness weights $\left(w_{1}, w_{2}, w_{3}\right)$ are determined as the left zero eigenvector of this matrix. To obtain equation (28) for the slow change in the population gene frequency we need to modify the first equation in (26) to

$$
\psi_{p s}=p q\left\langle b_{S i}+b_{I i} \frac{I}{S}+b_{R i} \frac{R}{S}-\mu_{i}-\beta_{i} I \mid p\right\rangle .
$$

Thus, the approximate fitness (29) becomes

$$
\begin{aligned}
s_{i}= & \frac{w_{1}}{\|w\|}\left(b_{S i}+b_{I i} \frac{I}{S}+b_{R i} \frac{R}{S}\right) \\
& -\mu_{i}-\left(\frac{w_{1}}{\|w\|} \frac{I}{S}-\frac{w_{2}}{\|w\|}\right) \beta_{i} S-\frac{w_{2}}{\|w\|} \alpha_{i}+\left(\frac{w_{3}}{\|w\|} \frac{I}{R}-\frac{w_{2}}{\|w\|}\right) \nu_{i} .
\end{aligned}
$$

This equation is exactly of the form (29) if we define the birth-rate deviation $b_{i}$ associated with genotype $i$ as the weighted average $b_{i}=\left(S b_{S i}+I b_{I i}+R b_{R i}\right) / N$ in the population at equilibrium. The change due to the heterogeneity in the birth rates is therefore reflected entirely in the weights $w$.

\section{EXamples of OTher Diseases}

The method can be applied to most other diseases described by SIR-type models. Here we consider two examples: a deathly disease with a latent period, and a disease which does not confer immunity to recovered individuals. We again assume that mortality $\mu(N)$ increases and birth rate $b(N)$ decreases with population size, and that the contact rate $\beta(N) N$ is not decreasing.

\subsection{Disease with a latent period}

Most contagious diseases do not cause the infected host to become infectious immediately after contracting the disease. To describe this we introduce a latent class $H$ of individuals who are infected but not yet infectious and we denote by $\eta$ the rate at which these individuals become infectious. For the sake of simplicity we assume that the disease is always deathly so that the dynamics becomes

$$
\begin{aligned}
& \frac{d S}{d t}=b N-\mu S-\beta S I \\
& \frac{d H}{d t}=\beta S I-(\eta+\mu) H \\
& \frac{d I}{d t}=\eta H-(\mu+\alpha) I .
\end{aligned}
$$

The disease free equilibrium $\hat{N}$ of model (34) is unstable when the reproduction number $\mathcal{R}(\hat{N})$,

$$
\mathcal{R}(N)=\frac{\beta(N) N}{\mu(N)+\alpha} \frac{\eta}{\eta+\mu(N)}
$$


exceed unity, where $\hat{N}$ is determined by $b(\hat{N})=\mu(\hat{N})$.

The genetic response to the disease is modeled as in section 4 . We write explicit expressions for the dynamics of each genotype and use the same methods as in the previous sections to obtain the equations for the change in gene frequency in each class

$$
\begin{aligned}
\frac{d p_{S}}{d t} & =b \frac{H}{S}\left(p_{H}=p_{S}\right)+b \frac{I}{S}\left(p_{\bar{I}}=p_{S}\right)+\varepsilon \psi_{p s} \\
\frac{d p_{H}}{d t} & =\beta S\left(p_{S}-p_{H}\right)+\varepsilon \psi_{p h} \\
\frac{d p_{R}}{d t} & =\eta \frac{H}{I}\left(p_{H}-p_{I}\right)+\varepsilon \psi_{p i}
\end{aligned}
$$

and for the change in deviation from Hardy-Weinberg proportions in each class

$$
\begin{aligned}
\frac{d F_{S}}{d t} & =b \frac{N}{S}\left(\frac{\left(\bar{p}-p_{S}\right)^{2}}{p_{S} q_{S}}\left(1-F_{S}\right)-\frac{\bar{p} \bar{q}}{p_{S} q_{S}} F_{S}\right)+\varepsilon \psi_{F S} \\
\frac{d F_{H}}{d t} & =\beta \frac{S I}{H}\left(\frac{\left(p_{S}-p_{H}\right)^{2}}{p_{H} q_{H}}\left(1-F_{H}\right)-\frac{p_{S} q_{S}}{p_{H} q_{H}}\left(F_{H}-F_{S}\right)\right)+\varepsilon \psi_{F H} \\
\frac{d F_{I}}{d t} & =\frac{\eta H}{I}\left(\frac{\left(p_{H}-p_{I}\right)^{2}}{p_{I} q_{I}}\left(1-F_{I}\right)-\frac{p_{H} q_{H}}{p_{I} q_{I}}\left(F_{I}-F_{H}\right)\right)+\varepsilon \psi_{F I}
\end{aligned}
$$

The model (34) of host regulation with a latent period can exhibit sustained oscillations (Anderson et al., 1981; Swart, 1989; Pugliese, 1990b) which was not possible in model (12). Provided that such oscillations do not occur and that disease transmission is sufficiently strong to allow an endemic disease equilibrium, it is seen that model (34)-(36) for $\varepsilon=0$ has a one dimensional stable singularity

$$
\varpi_{0}(p)=\left(S^{*}, H^{*}, I^{*}, p, p, p, 0,0,0\right),
$$

and we find the change in gene frequency along this manifold governed by

$$
\begin{gathered}
\frac{d p}{d t}=\varepsilon p q\left(\frac{N}{S} \frac{w_{1}}{\|w\|}\left\langle b_{i} \mid p\right\rangle-\left\langle\mu_{i} \mid p\right\rangle-\left(\frac{w_{1}}{\|w\|}-\frac{w_{2}}{\|w\|} \frac{S}{H}\right)\left\langle\beta_{i} I \mid p\right\rangle\right. \\
\left.-\left(\frac{w_{2}}{\|w\|}-\frac{w_{3}}{\|w\|} \frac{H}{I}\right)\left\langle\eta_{i} \mid p\right\rangle-\frac{w_{3}}{\|w\|}\left\langle\alpha_{i} \mid p\right\rangle\right),
\end{gathered}
$$

where $\left(w_{1}, w_{2}, w_{3}\right)=\left(\delta_{S} N, \delta_{H}(I+H), \delta_{I} I\right)$ measure the expected residence time in the various disease classes, $\delta_{S}=S /(b N)=(\mu+\beta I)^{-1}, \delta_{H}=H /(\beta S I)=(\mu+\eta)^{-1}$, and $\delta_{I}=I /(\eta H)=(\mu+\alpha)^{-1}$ (see equation (34)), and all quantities are evaluated at the endemic equilibrium. Thus, in this case the properties of models (15)-(17) and (34)-(36) are very similar. 
If model (34) settles to a periodic solution, we still can perform the projection onto the left hand eigenvector $w$ for each time $t$. (Our expression for $w$ will not hold, however, since we utilized the equilibrium conditions to simplify $w$.) The resulting equation for $p$ now takes the form

$$
\frac{d p}{d t}=\varepsilon g(t, p)+O\left(\varepsilon^{2}\right)
$$

where $g$ is periodic in $t$ with a period $T$ determined by the disease dynamics. Provided that the change in $p$ does not change significantly the dynamics of the disease one can use a standard averaging argument to see that $p$ is well approximated by

$$
\frac{d p_{1}}{d t}=\frac{1}{T} \int_{0}^{T} g\left(t, p_{1}\right) d t
$$

on the time interval $\left[t_{0} ; \varepsilon^{-1}\right]$ (Sanders and Verhulst, 1985; Murdock, 1991).

We do not know if model (34) can exhibit more complicated dynamics, but if aperiodic oscillations occur, we suggest the following averaging procedure. Let $\vartheta$ be the stationary density of the population states for $\varepsilon=0$, i. e., $\vartheta(S, H, I) d S d H d I$ is the probability that $\left(S^{*}(t), H^{*}(t), I^{*}(t)\right)$ is in a small neighborhood of $(S, H, I)$. We conjecture that $p$ may be found by

$$
\begin{aligned}
\frac{d p}{d t}=\varepsilon p q & \left(\int \frac{N}{S} \frac{w_{1}}{\|w\|} \vartheta d S d H d I\left\langle b_{i} \mid p\right\rangle-\left\langle\mu_{i} \mid p\right\rangle\right. \\
& -\left\langle\int\left(\frac{w_{1}}{\|w\|}-\frac{w_{2}}{\|w\|} \frac{S}{H}\right) \beta_{i} I \vartheta d S d H d I \mid p\right\rangle \\
& -\left\langle\int\left(\frac{w_{2}}{\|w\|}-\frac{w_{3}}{\|w\|} \frac{H}{I}\right) \eta_{i} \vartheta d S d H d I \mid p\right\rangle \\
& \left.-\left\langle\int \frac{w_{3}}{\|w\|} \alpha_{i} \vartheta d S d H d I\right|\right)
\end{aligned}
$$

where $\left(w_{1}, w_{2}, w_{3}\right)=\left(\beta(N) S^{2} E, b E(E+I), b I^{2} S / \eta\right)$ for any state of the disease model.

The reason for this decoupling of the variation in the disease states and the change in gene frequency is that as $\varepsilon \rightarrow 0$ the population will pass through an ever increasing number of population states before any appreciable change in gene frequency occurs. Thus, the conjecture follows from the law of large numbers (Christiansen, 1984), and we expect equation (39) to be an excellent approximation if model (34) exhibit a steady state of sustained oscillations with a short period.

\subsection{Disease without immunity of recovered individuals}

Consider a disease where individuals who recover from infection do not attain immunity and become susceptible immediately upon recovering. The disease dynamics then 
takes the form

$$
\begin{aligned}
& \frac{d S}{d t}=b N+\nu I-\mu S-\beta S I \\
& \frac{d I}{d t}=\beta S I-(\alpha+\nu+\mu) I .
\end{aligned}
$$

Using the methods of Pugliese (1990a) one can show that (40) has a stable endemic equi-librium exactly when the reproduction number $\mathcal{R}(\hat{N})$

$$
\mathcal{R}(N)=\frac{\beta(N) N}{\mu(N)+\nu+\alpha}
$$

exceed unity at the disease free equilibrium $\hat{N}$ where $\hat{N}$ is determined by $b(\hat{N})=\mu(\hat{N})$.

In case a stable endemic equilibrium exists, the computations are quite similar to the ones in the previous section and we obtain

$$
\begin{gathered}
\frac{d p}{d t}=\varepsilon p q\left(\frac{N}{S} \frac{w_{1}}{\|w\|}\left\langle b_{i} \mid p\right\rangle-\left\langle\mu_{i} \mid p\right\rangle-\left(\frac{w_{1}}{\|w\|} \frac{I}{S}-\frac{w_{2}}{\|w\|}\right)\left\langle\beta_{i} S \mid p\right\rangle\right. \\
\left.-\frac{w_{2}}{\|w\|}\left\langle\alpha_{i} \mid p\right\rangle+\left(\frac{w_{1}}{\|w\|} \frac{I}{S}-\frac{w_{2}}{\|w\|}\right)\left\langle\nu_{i} \mid p\right\rangle\right),
\end{gathered}
$$

where $w=(\beta S,(b+\nu) I / S)$. Note that variations in the two "transfer" parameters $\beta S$ and " carry exactly the same weight in the change of the gene frequency. The interpretation of the elements of the zero eigenvector $w$ in terms of conditional waiting times, $\delta_{S}=$ $S /(b N+\nu I)=(\mu+\beta I)^{-1}$ and $\delta_{I}=1 /(\beta S)=(\mu+\nu+\alpha)^{-1}$ (see equation (40)), is meaningless here, because these waiting times do not reflect the time spent in the two disease classes and weighing with the number of occurrences does not help.

\section{Numerical Solutions}

To investigate the performance of the approxmations, we compare numerically the values of $p$ found from the solutions of the exact system to those obtained from the approximations in three different cases: i) The simple SIR-model (14) with no density dependence in $\beta$ and $\mu$;i) the same SIR-model with seasonal variation in the transmission coefficient $\beta$; and iii) the SEI-model (34) in a situation where the model exhibits sustained oscillations.

As it is conventional in quasi steady state approximations, we in all cases assume that the gene frequency has not changed significantly during the initial transience where the system reaches equilibrium in the fast processes. Therefore we use the same initial conditions for the exact model and for the approximation. To reduce the effect of the transient, the initial conditions are chosen close to the endemic (disease) equilibrium, but, far from the genetic equilibrium. In our examples the demographic time scale, $b^{-1}$ or $\mu^{-1}$, 


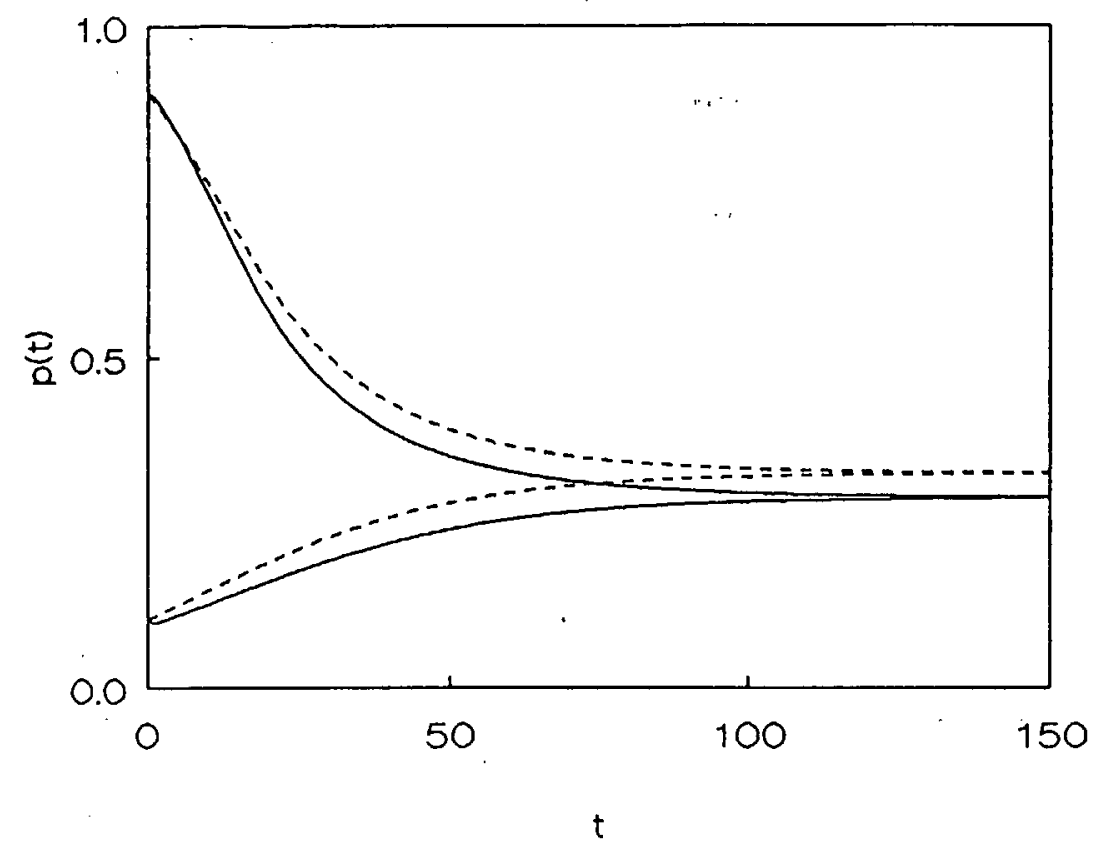

Figure 1. The true and approximate dynamics of $p$ in the variable population size SIR-model (14) for two sets of initial conditions. The parameter values are $b=2, \mu=1.5$, $\nu=500, \alpha=400, \beta=6$ and $\varepsilon=0.2$. The genotypic perturbations of the parameters are $\mu_{1}=1, \nu_{1}=500$, and $\alpha_{3}=400$ while the remaining perturbations are zero. The true value $p_{t}$ (solid line) is computed from the solution to (14) as $p_{t}=\left(p_{S} S+p_{I} I+p_{R} R\right) / N$ and the approximation $p_{a}$ (broken line) is determined from (28).

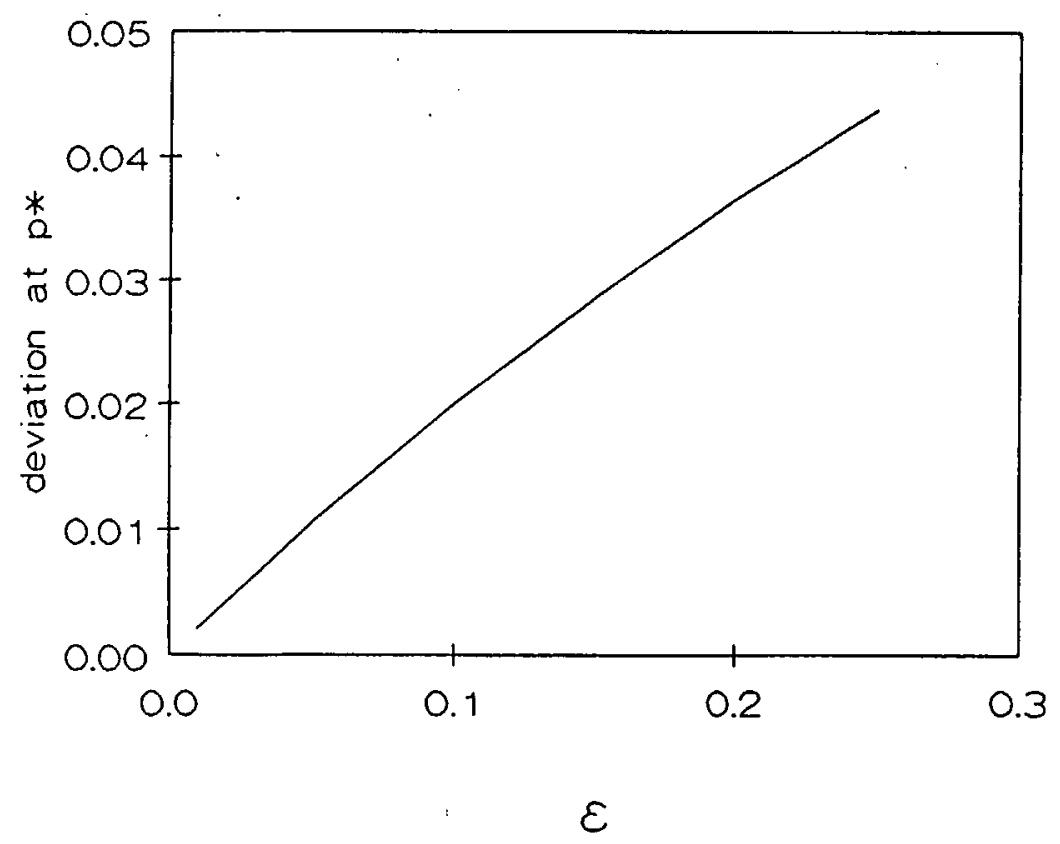

Figure 2. The error $\hat{p}_{a}-\hat{p}_{t}$ at equilibrium as a function of the size of the perturbation c. All other parameter values are as in Figure 1. 
is on the order of 1 while the genetic time scale $\varepsilon^{-1}(b / \varepsilon)$ is $5-10$ times larger. All numerical solutions are obtained using a 4th order Runge-Kutta algorithm with variable step size.

In the SIR-model with constant transmission coefficient, both disease incidence and gene frequency settles at an asymptotically stable equilibrium. For genotypic variations in the parameters of the order- $\varepsilon$ times-the parameter value, we find that at equilibrium the relative error of the approximate solution is of the order $\varepsilon$ and that the solution to the approximate equation for $p$ follows the value obtained from the solution of the exact equation (14) with an error less than $\bar{\varepsilon}$ (Fig. 1 and 2). These results appear to hold for $\varepsilon$ as large as 0.25 and in situations with ultimate polymorphism $\left(p=p^{*}\right)$ as well as in situations with fixation of the $a$ or $A$ gene $(p=0$ or 1$)$.

As expected the deviation from Hardy-Weinberg proportions, $F$ converge to an equilibrium of $\varepsilon$-magnitude on the fast time scale. Figure 3 shows the deviation $F_{I}$ in the infectious class, the class under the strongest selection. In the figure $\varepsilon=0.2$ while $F_{I}$ is considerably smaller, $F_{I}^{*} \approx-0.05$. This appears to be a general pattern: in all our numerical investigations, we find that $F$ deviates much less from 0 than promised by the analysis. This is expected, however, because the deviation from Hardy-Weinberg proportions depends principally on the dominance in fitness and to a lesser extent on the absolute magnitude of the fitness differences.

The parameter values in an SIR-model often vary by two to four orders of magnitude. For example the period of infectiousness $\nu^{-1}$ and the host life span $\mu^{-1}$ differ by several orders of magnitude for childhood diseases. Such a difference means that there may be a large difference in the numerical size of the parameter perturbations. Thus in Figure 1 for $\varepsilon=20 \%$, the genotypic perturbation to $\mu=1.5$ is $\mu_{1} \varepsilon=1 \times \varepsilon=0.2$ while the genotypic perturbation to $\alpha=400$ is $\alpha_{3} \varepsilon=400 \varepsilon=80.0$. Apparently the approximation works well in spite of this variation in the numerical size of the perturbations. This is probably due to the fact that the large parameters $\nu$ and $\alpha$ appear only in products with $I_{j}$. After a short transient phase we have $I / R=\nu^{-1} / \mu^{-1}=O(\mu /(\alpha+\nu)) \ll 1$ so the magnitude of the perturbations on $(\alpha+\nu) I$ is comparable to that of $\mu R$.

If the disease is truly epidemic, i.e. if the incidence varies over time, we conjecture that one must average over the stationary distribution as indicated in equation (39). To illustrate this situation we first introduce into the SIR-model (14) a seasonal variation in the transmission coefficient, $\beta$

$$
\beta_{i}(t)=\left(\beta+\varepsilon \beta_{i}\right)(1-c \cos \omega t)
$$

Dictz (1976) studied the parametric resonance arising in the SIR-model with fixed population size and seasonal transmission. A similar resonance occurs in (14) when the period of 


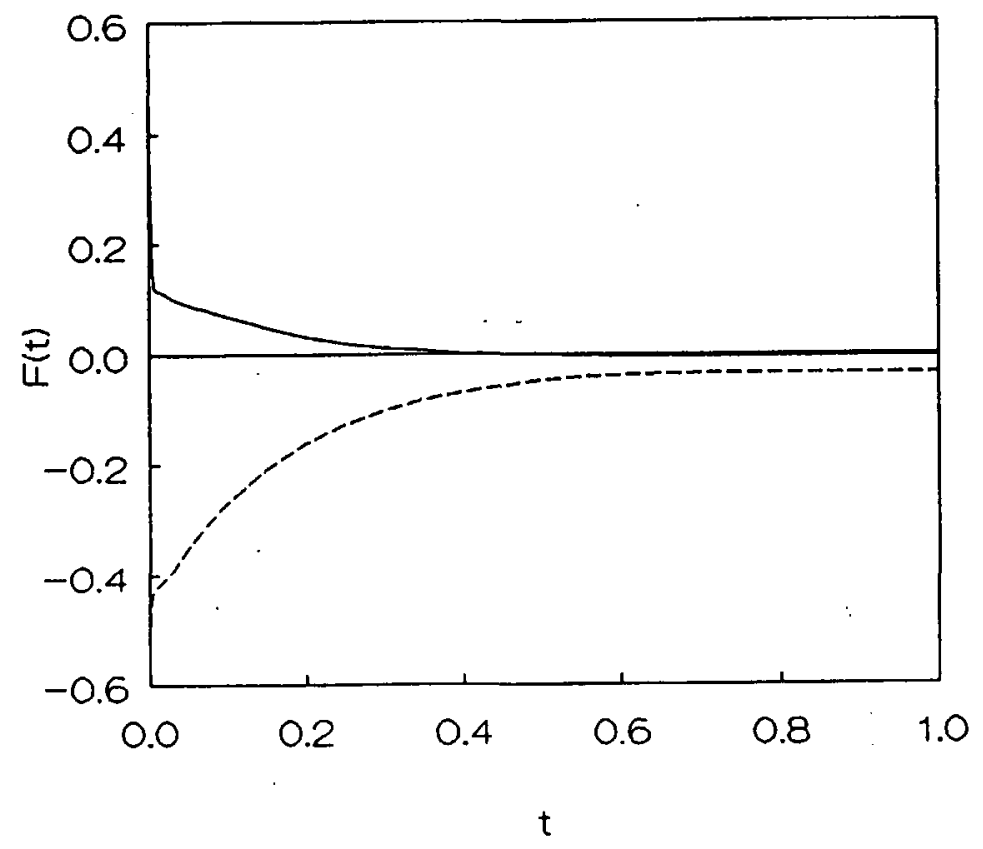

Figure 3. Deviations from Hardy-Weinberg proportions in the infectious class $F_{I}$ determined from the full model (14) for two sets of initial conditions. Our approximation assumes that $F_{I}=0$; notice the short time scale compared to Figure 1. All parameter values are as in Figure 1.

the forcing function $T=2 \pi / \omega$ coincides with the intrinsic period of the damped oscillation (Fig. 4).

The approximation to the change in gene frequency over time is obtained by averaging (28) over a full period $T$,

$$
\begin{aligned}
\frac{d p}{d t}=\varepsilon p q & \left(\int_{0}^{T} \frac{N(t)}{S(t)} \frac{w_{1}(t)}{\|w(t)\|} d t\left\langle b_{i} \mid p\right\rangle-\left\langle\mu_{i} \mid p\right\rangle\right. \\
& -\left\langle\frac{1}{T} \int_{0}^{T}\left(\frac{w_{1}(t)}{\|w(t)\|} \frac{I(t)}{S(t)}-\frac{w_{2}(t)}{\|w(t)\|}\right) \beta_{i}(t) S(t) d t \mid p\right\rangle \\
& \left.-\frac{1}{T} \int_{0}^{T} \frac{w_{2}(t)}{\|w(t)\|} d t\left\langle\alpha_{i} \mid p\right\rangle+\frac{1}{T} \int_{0}^{T}\left(\frac{w_{3}(t)}{\|w(t)\|} \frac{I(t)}{R(t)}-\frac{w_{2}(t)}{\|w(t)\|}\right) d t\left\langle\nu_{i} \mid p\right\rangle\right)
\end{aligned}
$$

where the weights $w$ are determined as

$$
w_{I}(t)=\left(\frac{S(t)}{b}, \frac{S(t)+I(t)}{\beta(t) S(t)}, \frac{R(t)^{2}}{\nu I(t)}\right)
$$


since this is a left hand eigenvector of $G_{p}^{\prime}(t)$ for all $t$. To find the integrand we solve numerically the SIR-model without genetics, equation (15) with (42), and integrate by summing over 400 points evenly spaced over one period.

Apparently the stability of the forced oscillation is so weak that the genetic variation in parameter values affects greatly both the amplitude of the oscillation and its baseline. Thus our assumptions that justify averaging out the fast time dynamics are not satisfied since the fast time dynamics change significantly with the slow time variable. However, in practice the method works remarkably well, Figure 5 .

The results are robust to changes in the details of the averaging procedure. Our simplified weights (25)

$$
w_{I I}(t)=\left(\frac{S(t)+I(t)+R(t)}{\beta(t) I(t)+\mu}, \frac{I(t)+R(t)}{\mu+\alpha+\nu}, \frac{R(t)}{\mu}\right)
$$

work just as well as $w_{I}$. Replacing the solution to $S, I$, and $R$ obtained from (34) with the values obtained from solving the full 9 -dimensional system has little effect. Insensitivity to the details of the averaging is known from Lotka-Volterra type models. Utilizing the special structure of Volterra systems Coste et al. (1978) showed that the time average of a variable goes to its equilibrium value as the averaging period goes to infinity.

Finally we investigate the situation where the disease induces autonomous oscillations in the disease incidence. Pugliese (1990b) shows that for density dependent disease transmission and mortality the SEI-model (34) may undergo a Hopf-bifurcation producing a stable limit cycle. We assume

$$
\begin{aligned}
\beta(N) & =\beta N^{-k} \\
\beta_{i}(N) & =\beta_{i} N^{-k} \quad \text { for } i=1,2,3, \\
\mu(N) & =\mu(1+N / K)
\end{aligned}
$$

and $\mu_{i}$ constant for $i=1,2,3$. A bifurcation analysis similar to that of Pugliese (1990b) shows that sustained oscillations occur only when the disease parameters $\eta$ and $\alpha$ are much greater than the demographic parameters $b$ and $\mu$. In all cases the rate of approach to the limit cycle is slow. Thus the separation of time scales between disease and genetics does not hold, and both amplitude and period of the disease dynamics are affected by the genetic structure of the population (Fig. 6).

Figure 7 shows the gene frequency $p(t)$ obtained from the full model specifying the dynamics of each genotype in each disease class and the approximation to $p(t)$ obtained by using equation (39) with $w(t)=\left(\beta(N) S^{2} E, b E(E+I), b I^{2} S / \eta\right)$. The approximation seems to work quite well, but we have no theoretical justification for this. 


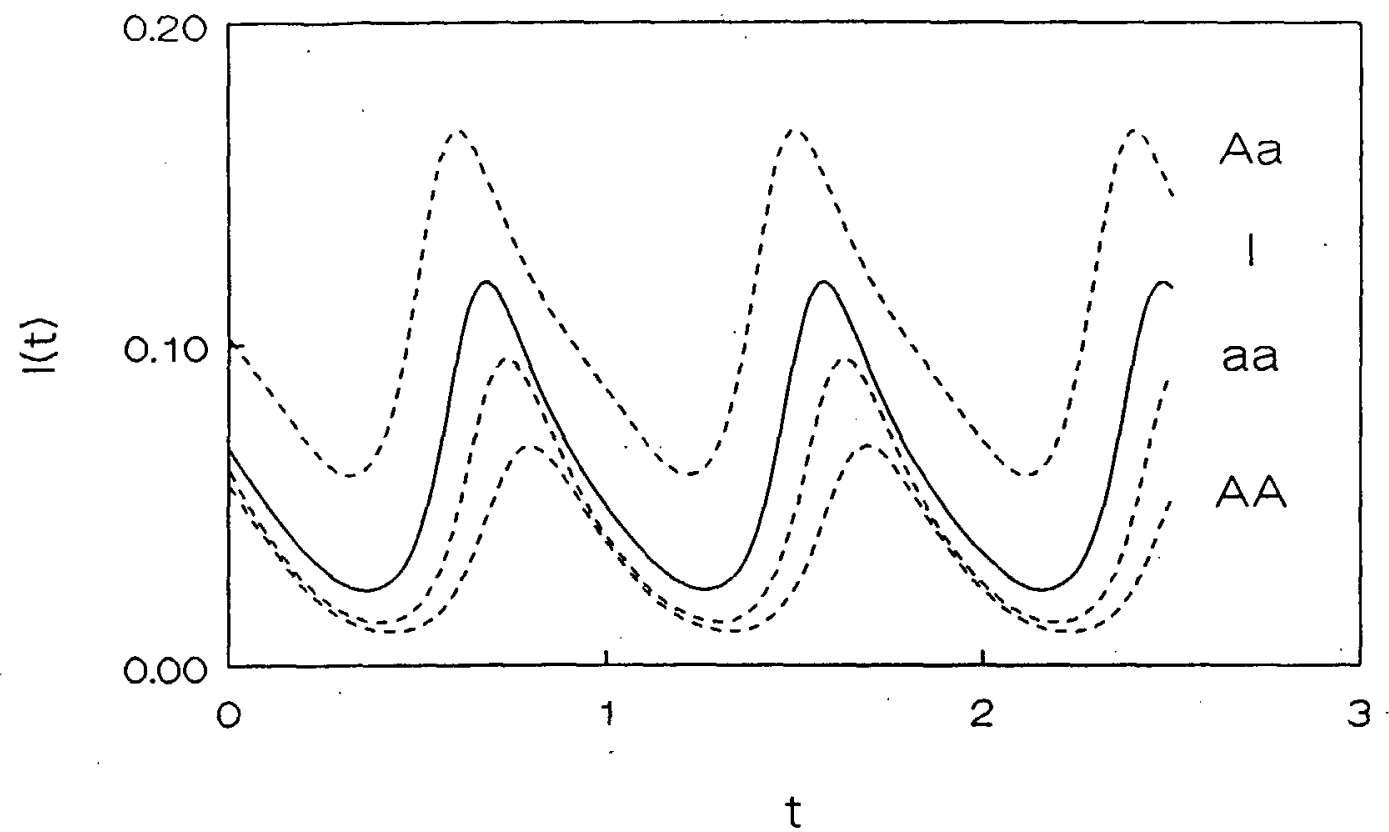

Figure 4. Forced oscillations in the variable population size SIR-model (14) with seasonally varying transmission coefficient (solid line). The broken lines show the oscillations in populations consisting entirely of one genotype. The parameter values are $b=2, \mu=1$, $\nu=3$, and $\alpha=5$. The transmission coefficient is $\beta(t)=\left(\beta+\varepsilon \beta_{i}\right)(1-c \cos \omega t)$ where $\beta=100, c=0.5$, and $\omega=7$. Resonance occurs at $\omega_{0}=7.08$. With $\varepsilon=0.2$, the perturbations are $\mu_{1}=1, \nu_{3}=-2$, and $\alpha_{3}=4$ while all other perturbations are 0 . Notice the large effect of the small genetic variation on disease incidence.

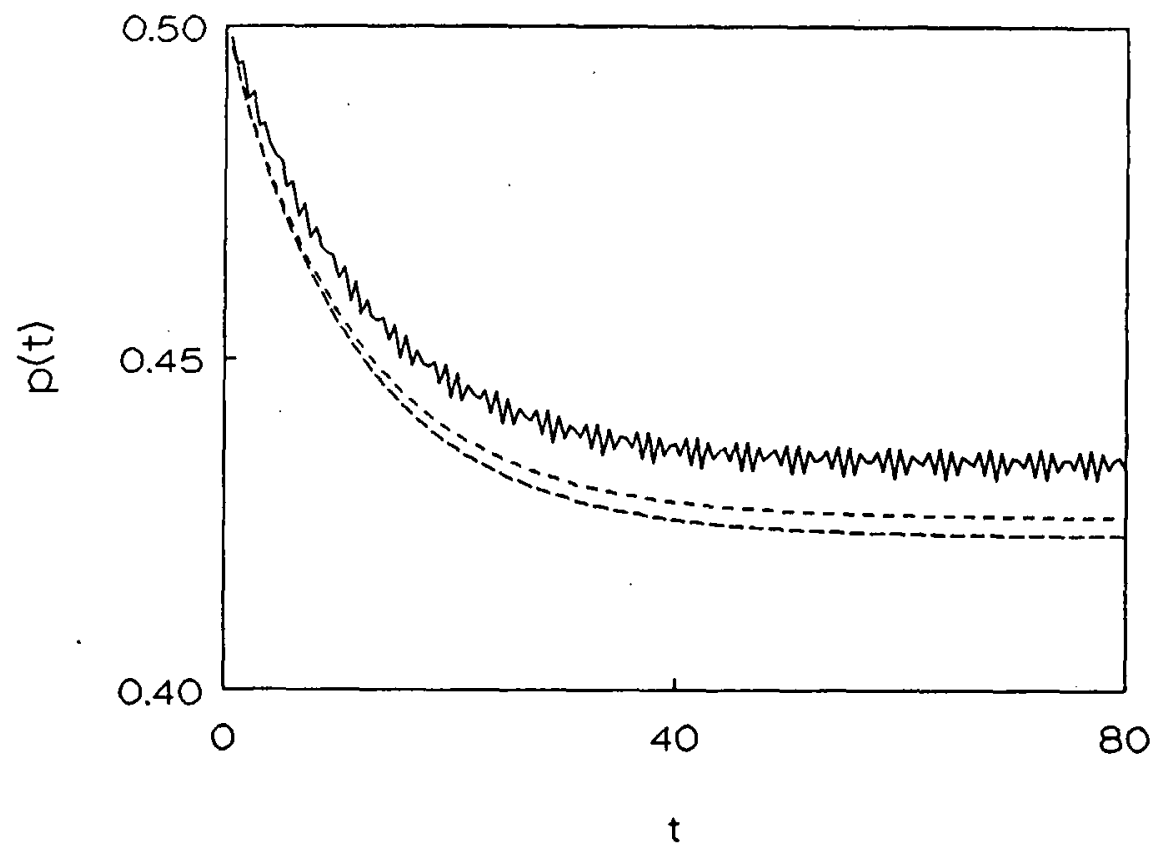

Figure 5. Exact (solid line) and approximate value of $p(t)$ for the SIR-model (14) with time dependent transmission and parameter values as in Figure 4. The meaning of the approximations I (short dashes) and II (long dashes) is discussed in the text. 


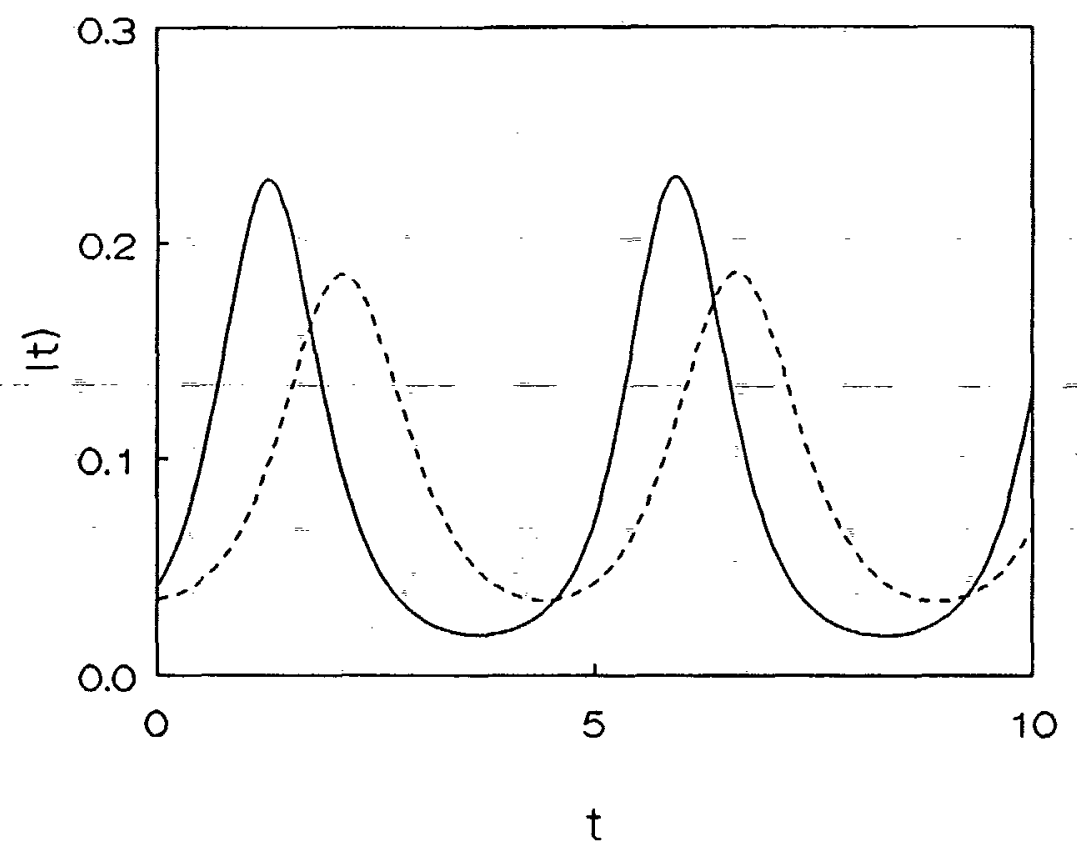

Figure 6. Sustained autonomous oscillations in the SEI-model (34) with density dependent transmission and mortality given by (44). The parameters are $b=1, \mu=0.5$, $K=100, \alpha=\eta=10, \sigma=7.6$, and $k=0.2$. With $\varepsilon=0.1$ the parameter perturbations are $\mu_{1}=1, \alpha_{3}=\eta_{3}=4, \beta_{3}=8$ and all other genotypic effects equal 0 . The exact value (solid line) is obtained from solving the full 9 dimensional system while the approximation (broken line) comes from solving (34). Notice the large effect of the genetic structure on disease incidence.

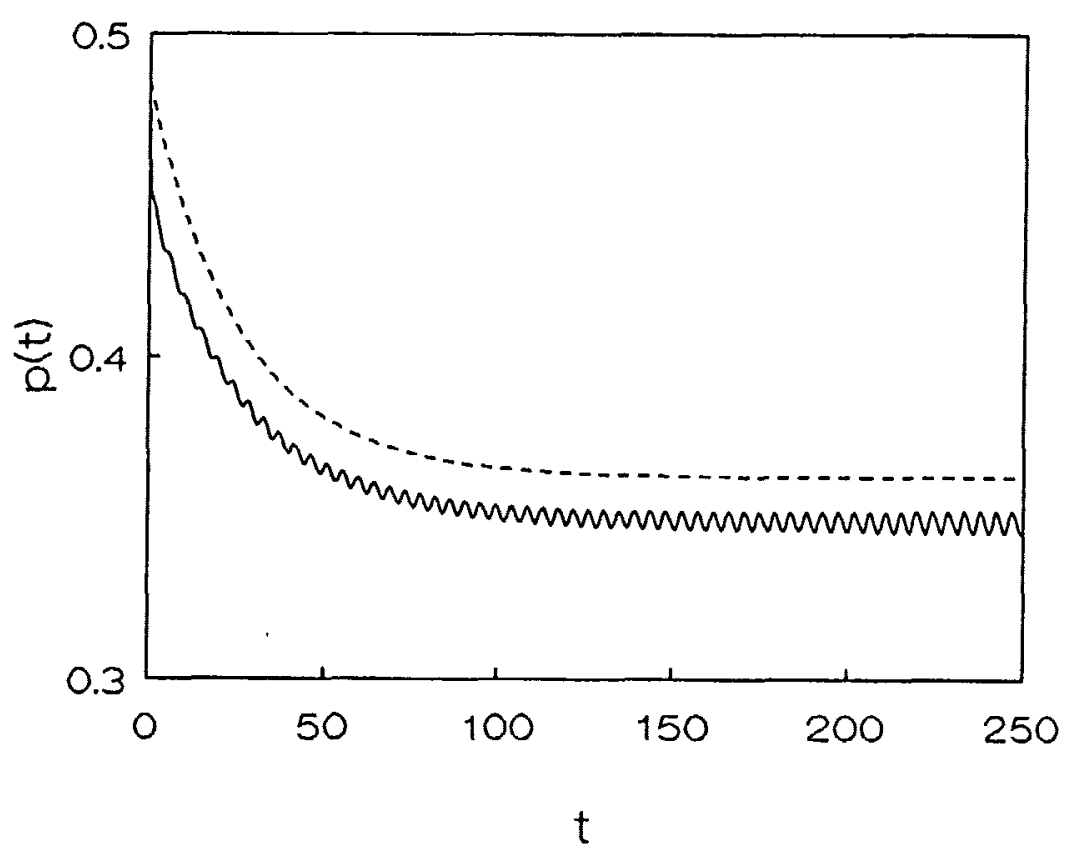

Figure 7. The dynamics of the gene frequency $p(t)$ in the SEI-model with density dependent transmission and mortality as in Figure 6. The exact value of $p(t)$ (solid line) is obtained from solving the full model and the approximation (broken line) is obtained by solving (37). 
Thus in all the three systems we have investigated, our approximation works well in spite of our expectation of problems in separating the time scales of the genetics and the disease.

\section{Discussion}

The existence of genetic variation in susceptibility and resistance to infectious diseases is well documented in farm animals and crop plants. For instance, associations between MHC-alleles and the occurrence or severity of infectious diseases are described in farm animals (Østergaard et al., 1989; Owen and Axford, 1991). These associations indicate genetic variation in various epidemiological parameters of a range of magnitudes. Loci with major resistance effects exists in the gene-for-gene systems of plant-fungal interactions, but more diffuse polygenic variation in susceptibility is known (Day, 1974).

The present models are especially suited for handling the evolution of polygenic variation in susceptibility. Each locus that influence the disease dynamics is then supposed to have a minor effect, and through the study of the slow evolution at one locus properties of the evolution of the lot of loci are predicted. The loci with major effects, however, are not necessarily excluded. An effect is viewed as major in terms of its detection, not necessarily in terms of its effect on epidemiological parameters. The slow selection approximation is not expected to describe the dynamics of major resistance genes well, even though the evolution of such genes in natural populations may differ substantially from the evolution in domesticated populations. The variation in genetically based resistance in Australian and European rabbits to the myxoma virus that was introduced 40 years ago (Fenner and Ratcliffe, 1965) may be illuminated by evaluations of the variation in the approximate fitnesses (29).

For human populations our method is not applicable to degenerative blood diseases such as sickle cell anemia and $\alpha$-thalassemia that promote malaria resistance since the genotypic variation in mortality is significant. However, recent findings indicate familial a.ggregation in mortality patterns for some infectious diseases (Sørensen et al., 1988). This inclicate genetic variation for susceptibility amenable to analysis by our models.

Due to the short life time of infectious virus and bacteria, disease transmission usually is modelled as a continuous process with few details about the course of the infection process. Geneticists often prefer a discrete time approach to account for the demographic details of sexual reproduction. A continuous time slow selection model allows us in a simple way to combine explicit descriptions of the two processes on the genotype level provided that the change in gene frequency is sufficiently slow to allow us to average over age-classes. The slow selection assumption allows us to break the system of equations into three parts. One that describes the transmission dynamics of the disease, one that 
describes the convergence of the genotypic frequencies to Hardy-Weinberg proportions, and a third part that specifies change in gene frequency. We formally develop this three-block separation by a straight forward coordinate transformation into coordinates $(N, p, F)$ that capture each of these processes.

The key to the transformation is Wright's fixation index $F$. The fixation index has nice dynamical properties in that for the neutral case, it will decrease to zero at an exponential rate equal to the birth rate of the population in question. When Beck et al. (1984) analyzed a slow selection approximation in a model similar to (14), they used a more complicated transformation. Therefore they were forced to leave crucial computations to a computer program of symbolic algebra manipulations. Apart from a couple of misprints we can reproduce the results of Beck et al. (1984) with less computational effort.

Nagylaki and Crow (1974), Aronson and Weinberger (1975) and Hunt (1980, 1982) use the absolute deviation $z=\left(4 x_{1} x_{3}-x_{2}^{2}\right) / N^{2}(=4 F p q)$ to measure the distance from Hardy-Weinberg proportions. In some respects $z$ has nicer analytical properties than the fixation index $F$, in that the transformation of rates between disease classes (Appendix 1, item 3) simplifies and $z$ has no singularity at the fixation boundaries $p=0$ and $p=1$. In spite of this we prefer $F$ since it is in essence frequency independent. Near the boundaries the range of variation of $z$ will approach zero irrespective of the genetic composition of the population while for all frequencies the fixation index $F$ varies between 1 and the larger of $-p / q$ and $-q / p$. So our result that $F$ approaches zero as the population approaches the boundary (section 4) show that the population will indeed reach Hardy-Weinberg proportions as it approaches the boundary.

In the transformed $(N, p, F)$-space, the separation in time scales becomes clear. The disease dynamics and convergence to Hardy-Weinberg proportions are fast, while the change in gene frequency is slow. In practice the separation of time scales may be hard to achieve since $S I R$-models themselves contain multiple time scales. Usually the duration of infection is much shorter than the population turn over time, e.g. for childhood diseases the ratio between these characteristic times may be as small as $10^{-3}-10^{-4}$. Numerical solutions show that our slow selection approximation works although the variation in fitness is up to $20 \%$.

The inherent presence of a slow time scale in disease models becomes more critical for epidemic diseases. Natural infectious diseases often exhibit large temporal variation in incidence, and we would like to extend our equilibrium results to such epidemic situations. By averaging the fitnesses over the stationary distribution of disease occurrence, we find good approximations to the true selection process for models with intrinsic or forced oscillations. This suggests a way to average over observed disease data in order to obtain the appropriate weights in the fitness expressions, and this approach is expected to work 
equally well for stochastic variations in the disease parameters (Christiansen, 1984). It is somewhat unclear why the averaging works. In general one can "average out" a fast. changing variable provided that it is independent of the slow variables (Sanders and Verhulst, 1985; Murdock, 1991). For disease models this is not satisfied, since the oscillations are only weakly stable leading to strong sensitivity to variations in parameter values. The averaging procedure, however, seems to be quite robust and this may explain its apparent success.

The transformation into $(N, p, F)$-space can be applied to other slow selection problems as well. Following the scheme from this paper, it is straight forward to write and analyze two-species competition and predator-prey models with slow selection. Our limited numerical investigations show that the neutrally stable limit cycles in the classical Lotka-Volterra model can not be averaged successfully while for a predator-prey model with a stable limit cycle the averaging procedure predicts the change in gene frequency with the expected accuracy. The dynamical properties of the fixation index should be useful in other situations, e.g. (age or spatially) structured populations.

Due to its short generation time and sloppy DNA-replication, evolutionary changes in viral pathogens can occur on the time scale we consider leading to an "evolutionary race" between host and pathogen (Haldane, 1949). Assuming small variation among two types of the disease, Beck (1984) extended the Beck et al. (1984) model to include competing viral strains. With our $(N, p, F)$-transformation we effortlessly can reproduce her results and obtain two equations for the slow change in the gene frequency of host and pathogen. Apparently the model for an SIR-type disease is degenerate in that the real part of a pair of complex eigenvalues changes sign without the creation of a limit cycle. Some aciditional biological effects must be included before the model meaningfully can describe host-pathogen coevolution.

\section{ACKNOLEDGEMENT}

This research was supported in parts by grant 11-8296 from the Danish Natural Science Research Council to VA. 


\section{APPENDIX A. First ORDER EXPRESSIONS FOR $d F / d t$}

In this and the subsequent appendix, we derive simple transformation rules that allow us to compute the dynamics of the new variables $N, p, F$ when the dynamics of the genotype variables $\left(x_{1}, x_{2}, x_{3}\right)$ are known, or in general to find the dynamics the variables $Q, p_{Q}, F_{Q}$ when the dynamics of the genotype variables $\left(Q_{1}, Q_{2}, Q_{3}\right), Q=S, I, R$ are given. For convenience we will use $u=2 N p$ and $v=2 N q$ to denote the number of alleles of the two types in the population, and $\dot{x}$ to denote the time derivative $d x / d t$.

1. The transformation is linear in the sense that if

$$
\dot{x}_{i}=a g_{i}(\ldots)+b h_{i}(\ldots)
$$

where $a$ and $b$ can be density and frequency dependent functions while $g_{i}$ and $h_{i}$ are genotype specific functions, then

$$
\dot{N}=a T_{N}(g)+b T_{N}(h)
$$

where $T_{N}(g)$ gives the dynamics of $N$ when $\dot{x}_{i}=g_{i}$.

The result is a simple consequence of the chain rule in that

$$
\begin{aligned}
\dot{N} & =\frac{\partial N}{\partial x_{1}} \dot{x}_{1}+\frac{\partial N}{\partial x_{2}} \dot{x}_{2}+\frac{\partial N}{\partial x_{1}} \dot{x}_{3} \\
& =a\left(\frac{\partial N}{\partial x_{1}} g_{1}+\frac{\partial N}{\partial x_{2}} g_{2}+\frac{\partial N}{\partial x_{1}} g_{3}\right)+b\left(\frac{\partial N}{\partial x_{1}} h_{1}+\frac{\partial N}{\partial x_{2}} h_{2}+\frac{\partial N}{\partial x_{1}} h_{3}\right) \\
& =a T_{N}(g)+b T_{N}(h) .
\end{aligned}
$$

The result obviously extends to $p$ and $F$. To obtain an autonomous differential equation in $(N, p, F)$ we still need (6) to express $a T_{N}(g)+b T_{N}(h)$ in terms of $(N, p, F)$, but the result shows that we may treat each term in the dynamics independently.

2. Vector fields of the form $\dot{x}_{i}=a x_{i}$ have no effect on $F$, i.e. if $\dot{x}_{i}=a x_{i}$ then $\dot{F}=0$. Notice that $a$ is the same for all genotypes but may be frequency and density dependent.

To see this observe that

$$
\begin{aligned}
\dot{F} & =\frac{4 x_{1} \dot{x}_{3}+4 x_{3} \dot{x}_{1}-2 x_{2} \dot{x}_{2}}{4 u v}-F\left(\frac{v \dot{u}}{u v}+\frac{u \dot{v}}{u v}\right) \\
& =2 a F-2 a F=0 .
\end{aligned}
$$

This observation indicates that processes with rates independent of the genotype will not affect the deviation from Hardy-Weinberg proportions. 
3. If $\dot{x}_{i}=y_{i}$ where $y_{i}$ is the abundance of genotype $i$ in another population (or disease class) then

$$
\dot{F}_{x}=\frac{y}{x .}\left(\frac{\left(p_{y}-p_{x}\right)^{2}}{p_{x} q_{x}}\left(1-F_{x}\right)-\frac{p_{y} q_{y}}{p_{x} q_{x}}\left(F_{x}-F_{y}\right)\right)
$$

where $x$. and $y$. are the total abundance of the two populations.

Here $p_{x}$ and $p_{y}$ denote the frequency of allele $A$ in the $x$ and the $y$ population respectively, while $F_{y}$ is the deviation from Hardy-Weinberg proportions for the $y$ population.

To see this we need (6) and some elementary algebra:

$$
\begin{aligned}
\dot{F}_{x}= & \frac{4 x_{1} y_{3}+4 x_{3} y_{1}-2 x_{2} y_{2}}{4 u_{x} v_{x}}-F_{x}\left(\frac{u_{y}}{u_{x}}+\frac{v_{y}}{v_{x}}\right) \\
= & \frac{y \cdot}{x} \frac{\left(\hat{p}_{x}^{2}+p_{x} q_{x} F_{x}\right)\left(q_{y}^{2}+p_{y} q_{y} F_{y}\right)+\left(q_{x}^{2}+p_{x} q_{x} F_{x}\right)\left(p_{y}^{2}+p_{y} q_{y} F_{y}\right)-2 p_{x} q_{x} p_{y} q_{y}\left(1-F_{x}\right)\left(1-F_{y}\right)}{p_{x} q_{x}} \\
& \quad-\frac{y}{x} F_{x}\left(\frac{p_{y}}{p_{x}}+\frac{q_{y}}{q_{x}}\right) \\
= & \frac{y \cdot}{x}\left(\frac{\left(p_{x} q_{y}-q_{x} p_{y}\right)^{2}}{p_{x} q_{x}}+F_{x}+\frac{p_{y} q_{y}}{p_{x} q_{x}} F_{y}-\frac{q_{x} p_{y}+p_{x} q_{y}}{p_{x} q_{x}} F_{x}\right) .
\end{aligned}
$$

Thus the mixing of two populations affects the deviation from Hardy-Weinberg in two ways. One effect is due to the difference in gene frequency among the populations and one effect is caused directly by differences in the values of $F$ in the two populations.

\section{ApPENdix B. SECOND order TERMS in $d p / d t$}

Since the first order dynamics of the allele frequency $p$ have a singularity, we need to compute the second order term in the $p$-component of the vector field. In general these terms are quite complicated. However, we need only evaluate them on the manifold $(N, p, F)=\left(N^{*}, p, 0\right)$ or in $\left(x_{1}, x_{2}, x_{3}\right)$-space

$$
\varpi_{0}(p)=\left(p^{2} N^{*}, 2 p q N^{*}, q^{2} N^{*}\right)
$$

By the chain rule the dynamics of the gene frequency $p$ becomes

$$
\dot{p}=\frac{2 \dot{x}_{1}+\dot{x}_{2}}{2 N}-p \frac{\dot{x}_{1}+\dot{x}_{2}+\dot{x}_{3}}{N}
$$

so if $\tilde{\psi}_{i}$ denotes the order $\varepsilon$ term in the dynamics of $x_{i}$ as in (4), the second order term in the equation for $\dot{p}$ is

$$
\psi_{p}=\left(\tilde{\psi}_{1} q+\frac{1}{2} \tilde{\psi}_{2}(q-p)-\tilde{\psi}_{3} p\right) / N
$$


On the manifold $\varpi_{0}(p)$ we get from (5)

$$
\begin{aligned}
& \tilde{\psi}_{1}\left(\varpi_{0}(p)\right)=p^{2} N r_{1} \\
& \tilde{\psi}_{2}\left(\varpi_{0}(p)\right)=2 p \dot{q} N r_{2} \\
& \tilde{\psi}_{3}\left(\varpi_{0}(p)\right)=q^{2} N r_{3},
\end{aligned}
$$

where $r_{i}=\overline{\bar{b}}_{i}\left(\varpi_{0}(p)\right)-\mu_{i}\left(\varpi_{0}(p)\right)$. Therefore, the second order terms in $\dot{p}$ reduce to

$$
\psi_{\bar{p}}=p q\left(\left(r_{1}-r_{2}\right) p-\left(r_{3}-r_{2}\right) q\right)
$$

In the epidemic model genes flow between disease classes. To handle this situation we need a minor modification of the preceding argument. The first order dynamics of $\left(p_{s}, p_{i}, p_{r}\right)$ have a similar singularity, and we compute the second order terms in the $p$ component on the manifold

$$
\begin{aligned}
\varpi_{0}(p) & =\left(S_{1}, S_{2}, S_{3}, I_{1}, I_{2}, I_{3}, R_{1}, R_{2}, R_{3}\right) \\
& =\left(p^{2} S^{*}, 2 p q S^{*}, q^{2} S^{*}, p^{2} I^{*}, 2 p q I^{*}, q^{2} I^{*}, p^{2} R^{*}, 2 p q R^{*}, q^{2} R^{*}\right) .
\end{aligned}
$$

Hence for the dynamics of the allele frequency $p_{Q}$ for the disease class $Q(Q=S, I, R)$, we get

$$
\psi_{p Q}=\frac{2 \tilde{\psi}_{Q 1}\left(\varpi_{0}(p)\right)+\tilde{\psi}_{Q 2}\left(\varpi_{0}(p)\right)}{2 Q^{*}}-\frac{\tilde{\psi}_{Q 1}\left(\varpi_{0}(p)\right)+\tilde{\psi}_{Q 2}\left(\varpi_{0}(p)\right)+\tilde{\psi}_{Q 3}\left(\varpi_{0}(p)\right)}{Q^{*}} p_{Q}
$$

The map from $\left(\tilde{\psi}_{Q 1}, \tilde{\psi}_{Q 2}, \tilde{\psi}_{Q 3}\right)$ to $\psi_{p Q}$ is linear according to the observations in Appendix $A$. We need only one additional property of this map:

If $\tilde{\psi}_{Q_{i}}=k_{i} P_{i}$ where $P=S, I, R$, and $k_{i}$ may be density and frequency dependent, then on the slow manifold $\varpi_{0}(p)$ we get the second order term

$$
\begin{aligned}
\psi_{p Q} & =\left(k_{1} p^{2}+k_{2} p q\right) \frac{P^{*}}{Q^{*}}-\left(k_{1} p^{2}+2 k_{2} p q+k_{3} q^{2}\right) \frac{P^{*}}{Q^{*}} p_{Q} \\
& =p q \frac{P^{*}}{Q^{*}}\left(p k_{1}+(1-2 p) k_{2}-q k_{3}\right) \\
& =p q \frac{P^{*}}{Q^{*}}\left\langle k_{i} \mid p\right\rangle
\end{aligned}
$$

where the last equality defines the meaning of $\langle\cdot \mid \cdot\rangle$. 


\section{REFERENCES}

Anderson, R. M. 1982. Directly transmitted viral and bacterial infections of man; in "The Population Dynamics of Infectious Diseases: Theory and Applications" (R. M. Anderson, ed.), pp. 1-37, Chapman and Hall, London.

Anclerson, R. M., and May, R. M. 1979. Population biology of infectious diseases: Part I, Nature, Lond. 280, 361-367.

Anderson, R. M., and May, R. M. 1982. Coevolution of hosts and parasites, Parasitology 85, 411-426.

Anderson, R. M., Jackson, H. C., May, R. M., and Smith, A. M. $1981 . \quad$ Population dynamics of fox rabies in Europe, Nature 289, 765-771.

Andreasen, V. 1989. Disease Regulation of Age-Structured Host Populations, Theor. Pop. Biol. 36, 214-239.

Aronson, D. G., and Weinberger, H. F. 1975. Nonlinear diffusion in population genetics, combustion, and nerve pulse propagation, in "Partial Differential Equations and Related Topics" (J. A. Goldstein, ed.), pp. 5-49, Springer-Verlag, Berlin.

Beck, K. 1984. Coevolution: Mathematical analysis of host-parasite interactions, J. Math. Biol. 19, 63-77.

Beck, K., Keener, J. P., and Ricciardi, P. 1984. The effect of epidemics on genetic evolution, J. Math. Biol. 19, 79-94.

Busenberg, S., and Driessche, P. van den 1990. Analysis of a disease transmission model in a population with varying size, J. Math. Biol. 28, 257-270.

Busenberg, S., and Hadeler, K. 1990. Demography and epidemics, Math. Biosci. 101, 63-74.

Christiansen, F. B. 1984. Evolution in a temporally varying environment: density and composition dependent genotypic fitness, in "Population Biology and Evolution" (K. Wöhrman and V. Loeschcke, eds.), pp. 115-124, Springer-Verlag, Berlin.

Christiansen, F. B. 1988. The Wahlund effect with overlapping generations, Amer. Natur. 131, 149-156.

Christiansen, F. B., and Fenchel, T. M. 1977. "Theories of Populations in Biological Communities," Springer-Verlag, Berlin.

Coddington, E. A., and Levinson, N. 1955. "Theory of Ordinary Differential Equations," McGraw-Hill, New York.

Coste, J., Peyraud, J., and P. Coullet 1978. Does complexity favor the existence of persistent ecosystems?, J. theor. Biol. 73, 359-362.

Crow, J. F., and Kimura, M. 1970. "An Introduction to Population Genetic Theory," Harper and Row, New York.

Day, P. R. 1974. "Genetics of Host-Parasite Interactions," Freeman, San Fransisco.

Dielimann, O., and Kretzschmar, M. 1991. Patterns in the effects of infectious diseases on population growth, J. Math. Biol. 29, 539-570.

Diet,z, K. 1975. Transmission and control of arbovirus diseases, in "Epidemiology" (D. Ludwig and K. L. Cooke, eds.), pp. 104-121, Society for Industrial and Applied 
Mathematics, Philadelphia.

Dietz, K. 1976. The incidence of infectious diseases under the influence of seasonal fluctuations, in "Mathematical Models in Medicine" (J. Berger et al, ed.), pp. 1-15, Springer, New York.

Feldman, M. W., Christiansen, F. B., and Liberman, U. 1983. On some models of fertility selection, Genetics 105, 1003-1010.

Fenner, F., and Ratcliffe, R. N. 1965. "Myxomatosis," Cambridge Univ. Press, London.

Fisher, R. A. 1930. "The Genetical Theory of Natural Selection," Clarendon Press, Oxford.

Freedman, M. I., and Waltman, P. 1978. Predator influence on the growth of a population with three genotypes, J. Math. Biol. 6, 367-374.

Getz, W. M., and Pickering, J. 1983 . Epidemic models: Thresholds and population regulation, Amer. Nat. 121, 892-898.

Gillespie, J. H. 1975. Natural selection for resistance to epidemics, Ecology 56, 493-495.

Haldane, J. B. S. 1949. Disease and evolution, Ricera Scient. (suppl.) 19, 68-76.

Hethcote, H. W. 1974. Asymptotic behavior and stability of epidemic models, in "Mathematical Problems in Biology" (P. van der Driessche, ed.), pp. 83-92, Springer, Berlin.

Hoppensteadt, F. 1966. Singular perturbations on the infinite interval, Trans. Amer. Math. Soc. 123, 521-535.

Hoppenstaedt, F. 1971. Properties of solutions of ordinary differential equations with small parameters, Comm. Pure Appl. Math. 24, 807-840.

Hoppensteadt, F. 1975. "Mathematical Theories of Populations: Demographics, Genetics and Epidemics," SIAM, Philadelphia.

Hunt, F. 1980. On the persistence of spatially homogeneous solutions of a population genetics model with slow selection, Math. Biosci. 52, 185-206.

Hunt, F. 1982. Regulation of population cycles by genetic feedback: Existence of periodic solutions of a mathematical model, J. Math. Biol. 13, 271-282.

Jayakar, S. D. 1970. A mathematical model for interaction of gene frequencies in a parasite and its host, Theor. Pop. Biol. 1, 140-164.

Kemper, J. T. 1982. The evolutionary effect of endemic infectious disease: Continuous models for an invariant pathogen, J. Math. Biol. 15, 65-77.

Kimura, M. 1958. On the change of population fitness by natural selection, Heredity 12, $145-167$.

Lewis, J. W. 1981. On the coevolution of pathogen and host: I. General theory of discrete time coevolution, J. theor. Biol. 93, 927-951.

Longini, I. M. 1983. Models of epidemics and endemicity in genetically variable host populations, J. Math. Biol. 17, 289-304.

May, R. M., and Anderson, R. M. 1983. Epidemiology and genetics in the coevolution of parasites and hosts, Proc. R. Soc. Lond. B219, 281-313.

Murdock, J. A. 1991. "Perturbations," Wiley, New York. 
Nagylaki, T. $1977 . \quad$ "Selection in One- and Two Locus Systems," Lecture Notès an Biomathematics 15, Springer-Verlag, Berlin.

Nagylaki, T., and Crow, J. F. 1974. Continuous selective models, Theor. Pop. Biol.5, $257-283$.

Nei, M. 1977. F-statistics and analysis of gene diversity in subdivided populations; Ann Hum. Genet., Lond. 41, 225-233.

Norton, H. T. J. 1928. Natural selection and Mendelian variation, Proc. Lond. Math. Soc: (ser. 2) 28, 1-45.

Østergaard, H., Kristensen, B., and Andersen, S. 1989. Investigations in farm animals of associations between the $\mathrm{MHC}$ system and disease resistance and fertility, Livestock Production Science 22, 49-67.

Owen, J. B., and Axford, R. F. E. 1991. "Breeding for Disease Resistance in Farm Animals," C. A. B. International, London.

Pugliese, A. 1990a. Population models for diseases with no recovery, J. Math. Biol. 28, $65-82$.

Pugliese, A. 1990b. An SEI epidemic model with varying population size (manuscript).

Sanders, J. A., and Verhulst, F. 1985. "Averaging Methods in Nonlinear Dynamical Systems," Springer, New York.

Swart, J. H. 1989. Hopf bifurcation and stable limit cycle behavior in the spread of infectious disease, with special application to fox rabies, Math. Biosci. 95, 199-207.

Sørensen, T. I. A., Nielsen, G. G., Andersen, P. K., and Teasdale, T. W. 1988. Genetic and environmental influences on premature death in adult adoptees, N. Engl. J. Med. 318, 727-732.

Wright, S. 1969. "Evolution and Genetics of Populations: Vol. 2 The Theory of Gene Frequencies," University of Chicago Press, Chicago. 
1/78 "TANKER OM EN PRAKSIS" - et matematikprojekt. Projektrapport af: Anne Jensen, Lena Lindenskov, Marianne Kesselhahn og Nicolai Lomholt. Vejleder: Anders Madsen

2/78 "OPTIMERING" - Menneskets for $\phi$ gede beherskelsesmuligheder af natur og samfund. Projektrappart af: Tom J. Andersen, Tommy R. Andersen, Gert Krenфe og Peter H. Lassen Vejleder: Bernhelm Boss.

3/78 "OPCAVESAMLING", breddekursus i fysik. Af: Lasse Rasmussen, Aaqe Bonde Kræmmer og Jens Högaard Jensen.

4/78 "TRE ESSAYS" - om matematikundervisnina, matematiklæreruddannelsen on videnskabsrindalismen .

Af: Mogens Niss

Nr. 4 er p.t. udgået.

5/78 "BIBLIOGRAFISK VEJLEDNING til studiet af DEN MODERNE FYSIKS HISTORIE"

Af: Helge Kragh.

Nr. 5 er p.t. udgået.

6/78 "NOGLE ARTIKLER OG DEBATINDLFG OM - læreruddannelse og undervisning $i$ fysik, og - de naturvidenskabelige fags situation efter studenteroprøret".

Af: Karin Beyer, Jens Højgaard Jensen og

Bent $C$. Jørgensen.

7/78 "MATEMATIKKENS FORHOLD TIL SAMFUNDS $\emptyset$ KONOMIEN" . Af: B.V. Gnedenko.

$\mathrm{Nr} .7$ er udgået.

8/78 "DYNAMIK OG DIAGRAMMER". Introduktion til energy-bond-graph formalismen. Af: Peder Voetmann Christiansen.

9/78 "OM PRAKSIS' INDFLYDELSE PA MATEMATIKKENS UD VIKLING". - Motiver t1l Kepler's: "Nova Stereometria Doliorum Vinariom".

Projektrapport af: Lasse Rasmussen.

Vejleder: Anders Madsen.

10/79 "TERMODYNAMIK I GYMNASIET". Projektrapport af: Jan Christensen og Jeanne Mortensen.

Vejledere: Karin Beyer og Peder Voetmann Christiansen.

11/79 "STATISTISKE MATERIALER". Af: Jørgen Larsen.

$12 / 79$ "LINEARE DIFFERENTIALLIGNINGER OG DIFFERENTIALLIGNINGSSYSTEMER" . Af: Mogens Brun Heefelt. $\mathrm{Nr}, 12$ er udgået.

$13 / 79$ "CAVENDISH'S FORS $\emptyset \mathrm{G}$ I GYMNASIET". Projektrapport af: Gert Kreinфe. Vejleder: Albert Chr. Paulsen.

14/79 "BOOKS ABOUT MATHEMATICS: History, Philosophy, Education, Models, System Theory, and Works of". Af : Lise Hфyrup.

Nr. 14 er p.t. udgået.

15/79 "STRUKTUREL STABILITET OG KATASTROFER 1 systemer $i$ og udenfor termodynamisk ligevægt". Specialeopgave af: Leif S. Striegler. Vejleder: Peder Voetmann Ckristiansen.

16/79 "STATISTIK I KREFTFORSKNINGEN". projektrapport af: Michael olsen oo Jørn Jensen. Vejleder: Jørgen Larsen.

$17 / 79$ "AT SPQRGE OG AT SVARE 1 fysikundervisningen". $\lambda f$ : Albert Christian Paulsen.
18/79 "MATHEMATICS AND THE REAL WORLD", Proceedings af an International Workshop, Roskilde University Centre, Denmark, 1978. Preprint.

Af: Bernhelm Booss og Mogens Niss (eds.)

19/79 "GEOMETRI, SKOLE OG VIRKELIGHED". Projektrapport áf: Tom J. Andersen, Tommy. R. Andersen og Per H.H. Larsen.

vejleder: Mogens Niss.

20/79 "STATISTISKE MDDELIER TIL BESTEMMETSE AF SIKRE DOSER FOR- CARCINOGENE STOFFER".

Projektrapport af: Michael Olsen og Jøm Jensen. Vejleder: Jorgen Larsen

21/79 "KONTROL I GIMNASIET-FOPMRL OG KONSEKVENSER". Projektrapport af: Crilles Bacher, Per S.Jensen, Preben Jensen og Torben Nysteen.

22/79 "SEMIOTIK OG SYSTEMEGENSKABER (1)". l-port linezrt response og støj $i$ fysikken. Af: Peder Voetmann Christiansen.

23/79 "ON THE HISTORY AF EARLY WAVE MECHANICS - with special emphasis on the role af realitivity". Af: Helge Kragh.

24/80 "MATEMATTKOPFATTELSER HOS 2.G'ERE".

$a+b$ 1. En analyse. 2. Interviewmateriale. Projektrapport af: Jan Christensen og Knud Lindhardt Rasmussen.

Vejleder: Mogens Niss.

25/80 "ERSAMENSOFGAVER", Dybdemodulet/fysik 1974-79.

26/80 "OM MATEMATISKE MDDETIER".

En projektrapport og to artikler.

Af: Jens Højgaard Jensen m. $\mathrm{fl}$.

27/80 "MEIHODOLOGY AND PHILOSOPHY AF SCIENCE IN PAUL DIRAC's PHYSICS". Af: Helge Kragh.

28/80 "DTRI HITRISK RELAXATION -..et forslag til en ny model bygget på vaskemes viscoelastiske egenskaber".

Projektrapport af: Gert Kreinфe.

Vejleder: Niels Boye Olsen.

29/80 "ODIN - undervisningsmateriale til et kursus $i$ differentialligningsmodeller".

Projektrapport af: Tosmy R. Andersen, Per H.H. Larsen og Peter H. Lassen.

Vejleder: Mogens Brun Heefelt.

30/80 "FUSIONSENERGIEN - - - ATOMSAMFUNDETS ENDESTATION".

Af: Oluf Danielsen.

$\mathrm{Nr} .30$ er udgået.

31/80 "VIDENSKMBSTEOREIISKE PROBLEMER VED UNDERVISNINGS SYSTEMER BASERET PA MPNGDETARE". Projektrapport af: Troels Lange og Jørgen Karrebak.

Vejleder: Stig Andur Pedersen.

Nr. 31 er p.t. udgået.

32/80 "POLMMERE STOIFERS VISCOEIASTISTEE ECENSKABER BELYST VED HJJELP AF MEKANISKE IMPEDANSMALIN GER MOSSBAUEREFFEKTMALINGER".

Projektrapport af: Crilles Bacher og Preben Jensen.

Vejledere: Niels Boye Olsen og Peder Voetmann Christiansen.

33/80 "KONSTTIUERING AF FAG INDEN FOR TEKNISK - NATURVIDENSKABEIIGE UDDANNEISER. I-II". Af: Arne Jakobsen.

34/80 "ENVIRONMENTAL IMPACT AF' WIND FNERGY UTTHIZATION".

ENEREY SERIES NO. I.

Af: Bent Sørensen

$\mathrm{Nr}$; 34 er udgået. 
.35/80 "HISTORISKE STUDIER I DEN NYERE ATOMFYSIKS UDVIKLING". Af: Helge Kragh.

36/80 "HVAD ER MENINGEN MED MATEMATIKUNDERNISNINGEN?". Fire artikler.

Af: Mogens Niss.

37/80 "RENEWABLE ENERCY AND ENERGY STORAGE". ENERGY SERIES NO. 2.

Af: Bent Sørensen.

38/81 "TII EN HISIORIETEORI OM NATURERKENDETSE; TEKNOLOGI OG SAMFUND".

Projektrapport af: Erik Gade, Hans Hedal, Henrik Lau og Finn Physant.

vejledere: Stig Andur Pedersen, Helge Kragh og Io Thiersen.

Nr. 38 er p.t. udgået.

39/81 "TII KRTITIKKEN AF VEKSTØKONOMIEN". Af: Jens Højgaard Jensen.

40/81 "TETEKOMMUNIKATION I DANMARK - oplæg til en teknologivurdering".

Projektrapport af: Arne Jørgensen, Brumo Petersen og Jan Vedde.

Vejleder: Per Nørgaard.

41/81 "PIANNING AND POL.ICY CONSIDERATIONS REIATED TO THE INTRODUCTION OF RENENABLE ENERCY SOURCES INTO ENERGY SUPPLY SYSTEMS".

ENERGY SERTES NO. 3

Af: Bent Sørensen.

42/81 "VIDENSKAB TEORI SAMFUND - En introcuktion t11 materialistiske videnskabsopfattelser". Af: Helge Kragh og Stig. Andur Pedersen.

43/81 1. "COMPARATTVE RISK ASSESSMENT OF TOTAL ENERGY SYSTEMS". 2. "ADVANTACES AND DISADVANTAGES OF DECENTRALIZATION". ENERGY SERTES NO. 4.

Af: Bent Sørensen.

44/81 "HISTORISKE UNDERS $\varnothing$ CEISER AF DE EKSPERTMENIELLE FORUDSEININGER FOR RUTHERFORDS ATOMMODEL". Projektrapport af: Niels Thor Nielsen. Vejleder: Bent $C$. Jorgensen.

45/82 Er aldrig udkommet.

$46 / 82$ "EKSEMPLARISK UNDERVISNING OG FYSISK ERKENDESE-

$1+11$ ILLUSTRERET VED TO EKSEMPLER". Projektrapport af: Torben 0.01 sen, Lasse Rasmussen og Niels Dreyer Sørensen.

Vejleder: Bent C. Jørgensen.

47/82 "BARSEBACK OG DET VERST OFFICIEITT-TANKEIIGE UHET D". ENERGY SERIES NO. 5 Af: Bent Sørensen.

48/82 "EN UNDERSQCELSE AF MATEMATIKUNDERNISNINGEN PA ADGANESKURSUS TIL KØBBENHAVNS TEKNIKIKUM". Projektrapport af: Lis Eilertzen, Jørgen Karrebok, Troels Lange, Preben Norregaard, Liss1 Pedesen, Laust Rishøj, Itll Røn og Isac Showiki. Vejleder: Mogens Niss.

49/82 "ANALYSE AF MUITISPEKTRALE SATELLITBIILEDER". Projektrapport af: Preben Nørreçaard.

Vejledere: Jørgen Larsen og Rasmus Ole Rasmussen.

50/82 "HERSLEV - MULIGIEDI:R FOR VEDVARENDE ENERGI I EN IANDSBY".

ENERGY SERIES NO, 6

Rapport af: Bent Christensen, Bent Hove Jensen, Dennis B. M 1 ler, Bjame Laursen, Bjame Lilllethorup og Jacob Morch Pedersen.

Vejleder: Bent Sørensen.

51/82 "HVAD KAN DER GOKESS FOR AT AFHJELLPE PIGERS BLOKERING OVERFOR MATEMATIK ?"

Projektrapport af: Lis Eilertzen, L1ssi Pedersen, L1ll Rọn og Susanne Stender.
52.82 "DESUSPPNSION OF SPTITTTNG EITTPTIC SYMBOIS". Af: Bernhelm Booss og Krzysztof Wojciechowiski.

53/82 "THE CONSTITUTION OF SUBJECTS IN ENGINEERTNG EDUCATION".

Af: Arne Jacobsen og Stig Andux Pedersen.

54/82 "FUTURES RESEARCH" - A Philosophical- Analysis of Its Subject-Matter and Methods. Af: Stig Andur Pedersen og Johannes Witt-Hansen.

55/82 "MATEMATISKE MODEILER" - Litteratur på Roskilde Untversitetsbibliotek.

En blografi.

Af: Else Høyrup.

Vedr. tekst nr. 55/82 se også tekst nr. 62/83.

56/82 "EN - TO - MANGE" -

En unders $\phi g e l s e$ af matematisk $\phi k o l o g i$. Projektrapport af: Troels Iange.

Vejleder: Anders Madsen.

57/83 "ASPECT ERSPERTMENTET"-

Skjulte variable i kvantemekanikken?

Projektrapport af: Tom Juul Andersen.

Vejleder: Peder Voetmann Christtansen.

Nr. 57 er udgået.

58/83 "MATEMATISKE VANDRINGER" - Modelbetragtninger over spredning af dyr mellem smaibiotoper i. agerlandet.

Projektrapport af: Per Hammershoj Jensen og Iene Vagn Rasmussen.

Vejleder: Jørgen Larsen.

59/83"THE METHODOLOGY OF ENERGY PLANNING" ENERGY SERTES NO. 7.

Af: Bent Sørensen.

60/83 "MATEMATISK MODEKSPERTISE"- et eksermpel. Projektrapport af: Erik O. Gade, Jørgen Karrebak og Preben Norregaand.

Vejleder: Anders Madsen.

61/83 "FYSIKS IDEOLOGISKE FUNKTION, SOM ET EKSEMPEI PA EN NATURVIDENSKAB - HISTORISK SET".

Projektrapport af: Annette Post Nielsen. Vejledere: Jens Høyrup, Jens Højgaand Jensen og Jørgen Vogellus.

62/83 "MATEMATISKE MODEILER" - Litteratur pă Roskilde Universitetsbibliotek.

En blografi 2. rev. udgave.

Af: Else Hoyrup.

63/83 "GREATTNG ENERGY FUTURES:A SHORT GUIDE TO ENERGY PLANNING"

ENERGY SERIES No. 8.

Af: David Crossley $\propto$ gent Sorensen.

64/83 "VON MATEMATIK UND KRTEG".

Af: Berhelm Booss og Jens Høyrup.

65/83 "ANVENDT MATEMATIK - TEORI ELIER PRAKSIS". Projektrapport af: Per Hedegård Andersen, KIrsten Habekost, Carsten Holst-Jensen, Annelise von Moos, Else Marie Pedersen og Erling Moller Pedersen.

Vejledere: Bernhelm Booss og Klaus Grünbaum.

66/83 "MATEMATISKE MDDEILER FOR PERIODISK SELEKTION I ESCHERTCHIA COLI".

Projektrapport af: Hanne Lisbet Nndersen, Ole Richard Jensen og Klavs Frisdahl. Vejledere: Jørgen Larsen og Anders Hede Madsen.

67/83 "ELEPSOIDE METODEN - EN NY METODE TII ITNEAR PRDGRAMMERING?"

Projektrapport af: Lone Billmann og Iars Boye Vejleder: Mogens Brun Heefelt.

68/83 "STOKASTISKE MODELTER I POPUIATIONSGENETIK" - til kritikken af teoriladede modeller. Projektrapport af: Lise Odgård Gade, Susanne Hansen, Michael Hvild og Frank Molgănd Olsen. Vejleder: Jørgen Larsen. 
69/83 "ELEVFORIDSAININTEER I FYSIK"

- en test 11.9 med kommentarer.

Af: Albert C. Paulsen.

70/83 "INDLARTNGS - OG FORMIDLINGSSPROBLEMER I MATEMATIK $P \AA$ VOKSENUNDERVISNINCSNIVEAU". Projektrapport af: Hanne Lisbet Andersen, Torben J. Andreasen, Svend Age Houmann, Helle Glenup Jensen, Keld Fl. Nielsen, Lene Vagn Rasmussen.

Vejleder: Klaus Grünbaum og Anders Hode Madsen.

71/83 "PIGER OG FYSIK" - et problem og en udfordring for skolen?

-Af: Karin Beyer, Sussanne Blegaa,-Birthe-olsen, Jette Reich og Mette Vedelsby.

72/83 "VERDEN IFQLGE PEIRCE" - to metafysiske essays, om og af C.S Peirce.

Af: Peder Voetmann Christiansen.

73/83 " "EN ENERGIANALYSE AF LANDBRUG" - $\phi$ kologisk contra traditionelt. ENERGY SERIES NO. 9

Specialeopgave 1 fysik af: Bent hove Jensen. Vejleder: Ront Sørensen.

74/84 "MINIATURISERING AF MIKROEIEIKIRONIK" - om v1denskabeliggjort teknologi og nytten af at lare fysik. Projektrapport af: Bodil Harder og Linda Szkotak Jensen.

Vejledere: Jens Højgaard Jensen og Bent C. Jøngensen.

75/84 "MATEMATTKUNDERVISNINGEN I FREMTIDENS GYMNASTUM" - Case: Linear progranmering. Projektrapport af: Morten Blomhdj, Klavs Frisdahl og Frank Molgaard Olsen.

Vejledere: Mbgens Brun Heefelt og Jens Bjømeboe.

76/84 "KERNEKRRAFT I DANMARK?" - Et høringssvar indkalat af miljoministeriet, med kritik af miljøstyrelsens rapporter af 15. marts 1984 .

ENERGY SERIES No. 10

$\lambda f:$ Niels Boye Olsen og Bent Sørensen.

77/84 "POLITISKE INDEKS - FUP ELIER FAKTA?" Opinionsunders $\varnothing$ gelser belyst ved statistiske modeller.

Projektrapport af: Svend Aqe Houmann, Keld Nielsen or Susanne Stencler.

Vejledere: Jørgen Larsen og Jens Bjørmeboe.

78/84 "JEVNSTRAMLIEININGSEVNE OG GITTERSTRUKTUT I AMORFT GERMANIUM".

Specialrapport af: Hans Hedal, Frank C. Ludvigsen og Finn C. Physant.

Vejleder: Niels Boye Olsen.

79\%84 "MATEMATIK OC ALMENDANNETSE".

Projektrapport af: Henrlk Coster, Mikael Wennerberg Johansen, Povl Kattler, Birgitte Lydholm og Morten Overgaard Nielsen.

Vejleder: Bemhelm Booss.

80/84 "KUTSUSMAIERIAIE TIL MATEMATIK B". Af: Mogens Brun Heefelt.

81/84 "FREKVENSAFHRNCIG IEDNINGSEWN I AMDRFT GERMANIUM". Spocialerapnort af: Jørgen Wind Petersen og Jan Christensen.

Vejleder: Niels Boye Olsen.

82/84 "MATENATIK - $O$ F FYSTKUNDERVISNINGEN I DET AUTOMATISEREDE SAMFUND".

Rapport fra et seminar afholdt i Hvidovre 25-27 april 1983.

Red.: Jens Hojgaard Jensen, Bent C. Jorrqensen oq Mogens Niss.
83/84 "ON THE QUANTIFICATION OF SECURITY": PEACE RESEARCH SERIES NO. I

Af: Bent Sørensen

nr. 83 er p.t. udgået

84/84 "NOGLE ARTIKLER OM MATEMATTK, FYSIK OG ALMENDANDEISE" Af: Jens Hळjgaard Jensen, Mogens Niss m. fl.

85/84 "CENIRIFUCALREXULATORER OG MATEMATIK".

Speclalerapport af: Per Hedegărd Andersen, Carsten HolstJensen, Else Marie Pedersen og Erling Moller Pedersen. Vejleder: Stig Andur Pedersen.

86/84 "SECURTYY IMPLICATIONS OF ALTERNATIVE DEFENSE OPTIONS FOR WESTEERN EUROPE"

PEACE RESEARCH SERIES NO. 2 Af: Bent Sфorensen.

87/84 "A STMPIE MODEL, OF AC HOPPING CONDUCITITIY IN DISORDERED SOLIDS". Af: Jeppe C. Dyre.

88/84 "RISE, FALL AND RESURRECTION OF INFTNITESTMALS". Af: Detlef Laugwitz.

89/84 "FJERNVARMEOPTIMERTNC" Af: Bjarne L1llethonup og Jacob Morch Pedersen.

90/84 "ENERGI I 1.G - EN TEORI FOR TILRETTELABGGEISE". Af: Albert Chr. Paulsen.

91/85 "KVANTEMEORI FOR GMNASIET"

1. Ixerervejledning

Projektrapport af: Biger Lundgren, Henning Sten Hansen og John Johansson.

Vejleder: Torsten Meyer.

92/85 "KVANIETBORI FOR GMMNASIET".

2. Materiale

Projektrapport af: Biger Lundgren, Henning Sten Hansen

og John Johansson.

Vejleder: Torsten Meyer.

93/85 "THE SEMIOTICS OF QUANIUM - NON - LOCALITY" Af: Peder Voetmann Christiansen.

94/85 "TFEEENIGHEDEN BOURBAKI - generalen, matematikeren og anden". Projektrapport af: Morten Blomh $\phi j$, Klavs Frisdahl og Frank M. Olsen.

Vejleder: Moxjunsi Niss.

95/85 "AN AIITERNATIV DEFENSE PLAN FOR WESTERN EUROPE". PFACE RESFARCH SERTES NO. 3 Af: Bent Sørensen

96/85"ASPEKTER VED KRAFTVARMEFORSYNING"

Af: Bjarne Lilletorup.

Vejleder: Bent Sørensen.

97/85 "ON THE PHYSICS OF A.C. HOPPING CONDUCTIVITY". Af: Jeppe C. Dyre.

98/85 "VALGMUIGHEDER I INFORMATIONSALDEREN". Af: Bent Sørensen.

99/85 "Der er langt fra O til R". Projektrapport af: Niels Jørgensen og Mikael Klintorp. Vejleder: StIg Andur Pedersen.

100/85 "TALSYSTEMETS OPBYGNING" Af: Mogens Niss.

101/85 "EXTENDED MOMENTUM THEORY FOR WINDMTUS IN PERTURBATTVE FORM" Af: Ganesh Sengupta.

102/85 OPSTHLTNG OG ANALYSE AF MATEMATISKE MODETIER, BELYST VED MODETIER OVER KOERS FODEROPTACELSE OG - OMSAINING" Projektrapport af: Lis Eileitzen, Kirsten Habekost, I111 Rфn og Susanne Stender. Vejleder: Klaus Grünbaum. 
103/85 "ØDSIE KOLDKRIGERE OG VIDENSKABENS LYSE IDEER". Projektrapport af: Niels ole Dam og Kurt Jensen. Vejleder: Bent Sørensen.

104/85 "ANALOCREGNEMASKINEN $\propto$ L LORENZIIININGER". Af: Jens Jæger.

105/85"THE FREQUENCY DEPENDENCE OF THF, SDFT.IFIC HEAT AF THE MIASS REANSITIOI".

Af: Tage Christensen.

"A SIMPLE MODEL AF AC HOPPING CONDUCTIVITY".

Af: Jeppe C. Dyre.

Contributions to the Thind International Conference

on the Structure of Non - Crystalline Materials held In Grenoble July 1985.

106/85 "QUANTUM THEORY OF EXTENDED PARTICIES". Af: Bent Sørensen.

107/85 "EN MYG GR INGEN EPIDIMI". - flodblindhed som eksempel på matematisk modellering af et epidemiologisk problem. Projektrapport af: Per Hedegånd Andersen, Lars Boye, CarstenHolst Jensen, Else Marie Pedersen og Erling Moller Pedersen.

Vejleder: Jesper Larsen.

108/85 "APPLICATIONS AND MODEIJIING IN THE MATEMATICS CUR RICULIM" - state and trends Af: Mogens Niss.

109/85 "COX I STUDIETIDFN" - Cox's regressionsmodel anvendt på studenteroplysninger fra Ruc. Projektrapport af: Mikael Wennerberg Johansen, Poul Katlex og Torben J. Andreasen. Vejleder: Jørgen Larsen.

110/85":PLANNING FOR SECURITY". Af: Bent Sørerisen

$111 / 85$ JORDEN RUNDT PA FLADE KORT". Projektrapport af: Birgit Andresen, Beatriz Quinones og Jinmy Staal. Vejleder: Mogens Niss.

112/85 "VIDENSKABELLIGGØREISE AF DANSK TEKNOLOGISK INNOVATION FREM TIL 1950 - BELYST VED EKSEMPLER". Projektrannort af: Erik Odgaard Gade, Hans Hedal. Frank C. Ludvigsen, Annette Post Nielsen og Finn Physant.

Vejleder: Claus Bryld og Bent C. Jørgensen.

113/85 "DESUSPENSION OF SPIITTING ELIIPTIC SYMBOIS $11 "$. Af: Bernhelm Booss og Krzysztof Wojciechowski.

114/85 "ANVENDELSE AF GRAFISKE METODER TIL ANALYSE AF KONTIGENSTABEILER". Projektrapport af: Lone B11lmann, Ole R. Jensen og Arine-Lise von Moos.

Vejleder: Jorgen Larsen.

115/85 "MATEMATIKKENS UDVIKLING OP TIL RENAESSANCEN". Af: Mogens Niss.

116/85 "A PHENOMENOLOGICAL MODEL FOR THE MEYERNEIDEL RULE" Af: Jeppe C. Dyre.

117/85 "KRAFT \& FJERNVAFMEOPTIMERING" Af: Jacob Morch Pedersen. Vejlieder: Bent Sørensen

118/85 "TILFELDIGHEDIN OG NODVINDIGIEDEN IFØLLE PEIRCE OG FYSIKKEN" Af: Peder Voetmann Christiansen

119/86 "DET ER GANSKE VIST - - EUKIIDS FEMLE POSTULAT KUNNE NOK SKABE RORE I ANDEDAMMEN".

Af: Iben Maj Christiansen

Vejleder: Mogens Niss.
120/86 "ET ANTAL STATISTISKE STANDARDMDELIER" Af: Jørgen Larsen

121/86"SIMUIATION I KONTINUERT TID" . Af: Peder Voetmann Christiansen.

122/86 "ON THE MECHANISM OF GIASS IONIC CONDUCTIVTTY". Af: Jeppe C. Dyre.

123/86 "GIMNASIEFYSIKKEN OG DEN STORE VERDEN". Fysiklærerforeningen, IMFUFA, RUC.

124/86 "OPCAVESAMLING I MATFMATIK" Samtlige opgaver stillet i tiden 1974-jan. 1986.

125/86 "OVBY, - systemet - en effektiv fotametrisk spektralklassifikation af B-,A- og F-stjemer". Projektrapport af: Birger Lundgren.

126/86 "OM UDVIKLINGEN AF DEN SPECIETLE RELATIVITETSTEORI". Projektrap:ort af: Lise Odgaard \& Linda Szkotak Jensen Vejledere: Karin Beyer \& Stig Andur Pedersen.

127/86 "GNLOIS' BIDRAG TIL UDVIÍLINGEN AF DFN ABSTRANTTE ALGEBRR".

Projektrapport af: Pernille sand, veine Larsen \& Lars Frandsen.

Vejleder: Mogens Niss.

128/86 "SMARKYB" - om ikke-standard analyse.

Projektrapport af: Niels Jørgensen \& Mikael klintorp. Vejleder: Jeppe Dyre.

12.9/86 "PHYSICS IN SOCIETY"

Lecture Notes 1983 (1986)

Af: Bent Sørensen

130/86 "Studies in wind Power" Af: Bent Sorensen

131/86 "FYSIK OG SFMFUND" - Et integreret fysik/historieprojekt on naturanskuelsens historiske udvikling og dens samfundsmæsige betingethed. Projektrapport af: Jakob Heckscher, Søren Brond, Andy wierød.

Vejledere: Jens Høyrup, Jørgen Vogelius, Jens Højgaard Jensen.

$132 / 86$ "FYSIK OG DANNELSE" Projektrapport af: Søren Brønd, Andy wierød. Vejledere: Karin Beyer, Jørgen Vogelius.

1.3.3/86 "CHERNOBYL ACCIDENT: ASSESSING THE DATA. ENERGY SERIES NO. 15. AF: Bent Sørensen.

134/87 "THE D.C. AND THE A.C. ELECTRICAL TRANSPORT IN ASSETE SYSTEM" Authors: M.B.El-Den, N.B.Olsen, Ib Høst Pedersen, Petr Visčŏr

135/87 "INTUITIONISTISK MATEMATIKS METODER OG ERKENDELSESTEORETISKE FORUDSFEININGER"

MASTEMATIKSPECIALE: Claus Larsen

Vejledere: Anton Jensen og Stig Andur Pedersen

136/87 "Mystisk og naturlig filosofi: En skitse af kristendamens forste $\circ g$ andet mode mod grask ti.losofi."

Projektrapport af Frank Colding Ludvigsen

Vejledere: Historie: Ib Thiersen

Fysik: Jens Højgaard Jensen

137/87 "HOPMODELLER FOR ELEKTRISK LEDNING I UORDNEDE FASTE STOFFER" - Resume af licentiatafhandling

Af: Jeppe Dyre

Vejledere: Niels Boye Olsen og

Peder Voetmann Christiansen. 
138/87 "JOSEPHSON EFFECT AND CIRCLE MAP."

Paper presented at The International Workshop on Teaching Nonl inear Phenomena at Universities and Schools, "Chaos in Education". Balaton, Hungary, 26 Apri1-2 May 1987.

By: Peder Voetmann Christiansen

13 9/87 "Machbarkeit nichtbeherrschbarer-Technik curch Fortschritte in der Erkennbarkeit der Natur"

Af: Bernhelm Booss-Bavnbek Martin Bohle--Carbonell

140/87 "ON THE TOPOLOGY OF SPACES OF HOLOMORPHIC MAPS" By: Jens Gravesen

141/87 "RADIOMETERS UDVIKLING AF BLODGASAPPARATUR ET TEKNOLOGIHISTORISK PROJEKT"

Projektrapport af Finn C. Physant

vejleder: Ib Thiersen

142/87 "The Calderon Projektor for Operators with Splitting Elliptic Symbols"

by: Bcrnhelm Booss-Bavnbek og Krzysztof: P. Wojcicchowski

143/87 "Kursusmateriale til Matematik på NAT-BAS" af: Mogens Brun Heefelt

144/87 "Context and Non-Locality - A Peircean Approach Paper presented at the Symposium on the Foundations of Modern Physics The Copenhagen Interpretation 60 Years after the Como Lecture. Joensuu, Finland, $6-8$ august 1987.

By: Peder Voetmann Christiansen

145/87 "AIMS AND SCOPE OF APPLICATIONS AND MOUEULING IN MATHEMATICS CURRICULA"

Manuscript of a plenary lecture delivered at ICMTA 3, Kassel, FRG 8.-11.9.1987

By: Mogens Niss

146/87 "BESTEMMELSE AF BULKRESISTIVITETEN I SILICIUM"

- en ny frekvensbaseret målemetode.

Fysikspeciale af Jan Vedde

Vejledere: Niels Boye Olsen \& Petr Viščor

147/87 "Rapport on BIS på NAT-BAS"

redigeret af: Mogens Brun Heefelt

148/87 "Naturvidenskabsundervisning med

Samfundsperspektiv"

af: Peter Colding-Jargensen DLH

Albert Chr. Paulsen

149/87 "In-Situ Measurements of the density of amorphous germanium prepared in ultra high vacuum" by: Petr Viščor

150/87 "Structure and the Existence of the first sharp diffraction peak in amorphous germanium prepared in UHV and measured in-situ" by: Petr Viščr

151/87 "DYNAMISK PROGRAMMERING"

Matematikprojekt ar:

Birgit Andresen, Keld Nielsen og Jimmy Staa?

Vejleder: Mogens Niss
152/87 "PSEUDO-DIFFEREN'IIAL PROJECTIONS AND THE TOPOLOGY OF CERTAIN SPACES OF ELLIPTIC BOUNDARY VALUE PROBLEMS"

by: Bernhelm Booss-Bavnbek Krzysztof P. Wojciechowski

153/88 "HALVLEDERTEKNOLOGIENS UDVIKLING MELLEM MILITERE OG CIVILE KREFTER"

Et eksempel på humanistisk teknologihistorie Historiespeciale

Af:_Hans Hedal

Vejleder: Ib Thiersen

154/88 "MASTER EQUATION APPROACH TO VISCOUS LIQUIDS AND THE GLASS TRANSTTION"

By: Jeppe Dyre

155/88 "A NOTE ON THE ACTION OF THE POISSON SOLUTION OPERATOR TO THE DIRICHLET PROBLEM FOR A FORMALLY SELFADJOINT DIFFERENTIAL OPERATOR"

by: Michael Pedersen

156/88 "THE RANDOM FREE ENERGY BARRIER MODEL FOR AC CONDUCTION IN DISORDERED SOLIDS"

by: Jeppo C. Dyre

$157 / 88$ " STABILIZATION OF PARTIAL DIFFERENTIAL EQUATIONS BY FINITE DIMENSIONAL BOUNDARY FEEDBACK CONTROL : A pseudo-differential approach."

by: Michael Pedersen

158/88 "UNIFIED FORMALISM FOR EXCESS CURRENT NOISE IN RANDOM WALK MODELS"

by: Jeppe Dyre

$159 / 88$ "STUDIES IN SOLAR ENERGY"

by: Bent Sørensen

160/88 "LOOP GROUPS AND INSTANTONS IN DIMENSION TWO" by: Jens Gravesen

161/88 "PSEUDO-DIFFERENTIAL PERTURBATIONS AND STABILIZATION OF DISTRIBUTED PARAMETER SYSTEMS

Dirichlet feedback control problems"

by: Michael Pedersen

162/88 "PIGER \& FYSIK - OG MEGET MERE"

AF: Karin Beyer, Sussanne Blegaa, Birthe Olsen, Jette Reich, Mette Vedelsby

163/88 "EN MATEMATISK MODEL TIL BESTEMMELSE AF PERMEABILITETEN FOR BLOD-NETHINDE-BARRIEREN"

Af: Finn Langberg, Michael Jarden, Lars Frellesen

Vejleder: Jesper Larsen

164/88 "Vurdering af matematisk teknologi

Technology Assessment

Technikfolgenabschätzung"

Af: Bernhelm Booss-Bavnbek, Glen Pate med Martin Bohle-Carbonell og Jens Hojgaard Jensen

165/88 "COMPLEX STRUGTURES IN THE NASH-MOSER CATEGORY" by: Jens Gravesen 
166/88 "Grundbcgreber i Sandsynlighedsregningen":

Af: Jorgen Larsen

167a/88 "BASISSTATISTIK 1. Diskrete modeller" Af: Jorgen Larsen

167b/88 "BASISSTATISTJK 2. Kontinuerte modeller"

Af: Jorgen Larsen

168/88 "OVERFLADEN AF PLANETEN MARS" Laboratorie-simulering og MARS-analoger undersøgt ved Mössbauerspektroskopi.

Fysikspeciale af:

Birger Lundgren

Vejleder: Jens Martin Knudsen Fys.Lab./HCO

169/88 "CHARLES S. PEIRCE: MURSTEN OG MORTEL TIL EN METAFYSIK."

Fom artikler fra tidsskriftet "The Monist" 1891-93.

Introduktion og oversættelse:

Peder Voetmann Christeansen

170/88 "OPGAVESAMLING I MATEMATIK"

Samtlige opgaver stillet $i$ tiden

1974 - juni 1988

$171 / 88$ "The Dirac Equation with Light-Cone Data" af: Johnny Tom Ottesen

172/88 "FYSIK OG VIRKELIGHED"

Kvantemekanikkins grundlagsproblem i gyminasiet.

Fysikprojekt af:

Erik Lund og Kurt Jensen

Vejledere: Albert Chr. Paulsen og

Peder Voetmann Christiansen

173/89 "NUMERISKE ALGORITMER"

af: Mogens Brun Heefelt

174/89 " GRAFISK FREMSTILLING AF FRAKTALER OG KAOS"

af: Peder Voetmann Christiansen

175/89" AN ELEMENTARY ANALYSIS OF THE TIME DEPENDENT SPECTRIM OF THE NON-STATONARY SOLUTION TO THE OPERATOR RICCATI EQUATION af: Michael Pedersen

176/89" A MAXIUM ENTROPY ANSATZ FOR NONLINEAR RESPONSE THEORY"

af : Jeppe Dyre

$177 / 89$ "HVAD SKAL ADAM STA MODEL TIL" af: Morten Andersen, Ulla Engström. Thomas Gravesen, Nanna Lund, Pia Madsen, Dina Rawat, Peter Torstensen Vejleder: Mogens Brun Heefelt
178/89 "BIOSYNTESEN AF PENICILLIN - en matematisk modelit af: U1la Eghave Rasmussen, Hans Oxvang Mortensen, Michael Jarden

vejleder $i$ matematik: Jesper Larsen biologi: Erling Lauridsen

179a/89 "LERERVEJLEDNING M.M. til et ektperimentelt forla om kaos"

af: Andy Wierød, Søren Brønd og Jimmy Staai:

Vejledere: Peder Voetmann Christiansen Karin Beyer

179b/89 "ELEVHEFTE: Noter til et eksperimentelt kursus om kaos"

af: Andy Wierød, Søren Brønd og Jimmy Staal

Vejledere: Peder Voetmann Christiansen Karin Beyer

180/89. "KAOS I FYSISKE SYSTEMER eksemplificeret ved torsions- og dobbel tpendul".

af: Andy Wierod, Seren Brond og Jimmy staal

Vefleder: Peder Voetmann Christiansen

181/89 "A ZERO-PARAMETER CONSTITUTIVE RELATION"FOR PURE SHEAR VISCOELASTICITY"

by: Jeppe Dyre

183/89 "MATEMATICAL PROBLEM SOLVING, MODELLING. APPLICATIONS AND LIKKS TO OTHER SUBUBCTS - state. triends and issues in mathematics instruction

by: WRRNER BLUN, Kasgel (FRG) Og MOGENS NISS, Roskilde (Denmark)

184/89 "Bn metode til bestemnelse af den frekvensafhangige varmefylde of en underafkolet væske ved glasovergangen" af: Tage Bmil Christiensen

185/90 "EN NESTEN PERIODISK HISTORIE"

Et matematisk projekt

af: Steen Grode og Thomas Jessen

Vejleder: Jacob Jacobsen

186/90 "RITUAL OG RATIONALITET i videnskabers udvikling" redigeret af Arne Jakobsen og Stig Andur Pedersen

187/90 "RSA - et kryptografisk system"

af: Annemette Sofie Olufsen, Lars Frellesen og Ole Moller Nielsen

Vejledere: Michael Pedersen og Finn Munk

188/90 "FERMICONDENSATION - AN ALMOST IDEAL GLASS TRANSITION" by: Jeppe Dyre

189/90 "DATAMATER I MATFMATIKUNDERVISNINGEN PA GYMNASIET OG HØJERE LEREANSTALTER

af: Finn Langberg 
190/90 "FIVE REQUIREMENTS FOR AN APPROXIMATE NONLINEAR RESPONSE THEORY"

by: Jeppe Dyre

19.1/90 "MOORE COHOMOLOGY, PRINCIPAL BUNDLES AND ACTIONS OF GROUPS ON $C^{*}$-ALGEBRAS" by: Iain Raeburn and Dana P. Williams

$192 / 90$ "Age-dependent host mortality in the dynamics of endemic infectious diseases and

SIR-models of the epidemiology and natural selection of co-circulating-influenza virus with partial cross-immunity"

by: Viggo Andreasen

193/90 "Causal and Diagnostic Reasoning"

by: Stig Andur Pedersen

194a/90 "DETERMINISTISK KAOS"

Projektrapport af : Frank Olsen

194b/90 "DETERMINISTISK KAOS"

Korselsrapport

Projektrapport af: Frank OIsen

195/90 "STADLER PÅ PARADIGMETS VEJ"

Et projekt om den videnskabelige udvikling der forte til dannelse of kvantemekanikken. Projektrapport for 1 . modul på fysikuddannelsen, skrevet af:

Anja Boisen. Thomas Hougård, Anders Gorm Larsen, Nicolai Ryge.

Vejleder: Peder Voetmann Christiansen

196/90 "ER KAOS NØDVENDIGT?"

- en projektrapport on kaos' paradigmatiske status $i$ fysikken.

af: Johannes $K$. Nielsen; Jimmy Staal og Peter Boggild

Vejleder: Peder Voetmann Christiansen

] 97/90 "Kontrafaktiske konditionaler $\& \mathrm{HOL}$

af: Jesper Voetmann, Hans Oxvang Mortensen og Aleksander Host-Madsen

Vejleder: Stig Andur Pedersen

198/90 "Metal-1solator-Metal systemer"

Speciale

af: Frank Olsen

199/90 "SPREDT FAGTNING" Artikelsamling af: Jens Højgaard Jensen

200/90 "LINEAR ALGEBRA OG ANALYSE"

Noter til den naturvidenskabelige basisuddannelse.

af: Mogens Niss
201/90 "Undersogelse af atomare korrelationer i anorfe stoffer ved rontgendiffraktion" af: Karen Blrkelund og Klaus Dahl Jensen Vejledere: Petr Viǧčor, Ole Bakander

202/90 "TEGN OG KVANTER"

Foredrag og artikler, 1971-90.

af: Peder Voetmann Christiansen

203/90 "OPGAVESAMLING I MATEMATIK" 1974-1990 afloser tekst $170 / 88$

204/91 "ERKENDELSE OG RVANTEMEKANIK" et Breddemodul Fysik Projekt af: Thomas Jessen Vejleder: petr viśöor

205/91 "PEIRCE'S LOGIC OF VAGUENESS"

by: Claudine Engel-Tiercelin Department of Philosophy Université de Paris-1 (Panthéon-Sorbonne)

206a+b/91" GERMANIUMBEAMANALYSE SAMT A - GE TYNDFILMS ELEKTRISKE EGENSRABER ${ }^{\text {" }}$

Eksperimentelt Fysikspeciale

af: Jeanne Linda Mortensen

og Annette Post Nielsen vejleder: petr viščor

207/91 "SOME REMARKS ON AC CONDUCTION IN DISORDERED SOL IDS"

by: Jeppe C. Dyre

$208 / 91$ "LANGEV IN MODELS FOR SHEAR STRESS FLUCTUATIONS IN FLOWS OF VISCOELASTIC LIOUIDS"

by: Jeppe C. Dyre

209/91 "LORENZ GUIDE" Kompendium $t$ il den danske fysiker Ludvig Lorenz, 1829-91.

af : Helge Kragh

$210 / 91$ "Global Dimension, Tower of Algebras. and Jones Index of Split Seperable Subalgebras with Unitality Condition.

by: Lars Kadison

211/91 "T SANDHEDENSF TrTENESTF"

- historien bag teorien for de komplekse tal.

af: Lise Arleth, Charlotte Gjerrild, Jane Hansen, Linda Kyndlev, Anne Charlotte Nilsson. Kamma Tulinius.

Vejledere: desper Larsen og Bernhelm Booss-Baunbek

212/91 "Cyclia Homology of Triangular Matrix Algrimas"

by: Lars Kadison 